\title{
BIM Application for Sustainable Teaching Environment and Solutions in the Context of COVID-19
}

\author{
Iñigo Leon *(D), Maialen Sagarna $\mathbb{D}$, Fernando Mora and Juan Pedro Otaduy * \\ Department of Architecture, University of the Basque Country UPV/EHU, Plaza Oñati 2, \\ 20018 Donostia-San Sebastián, Spain; maialen.sagarna@ehu.eus (M.S.); fernando.mora@ehu.eus (F.M.) \\ * Correspondence: inigo.leon@ehu.eus (I.L.); juanpedro.otaduy@ehu.eus (J.P.O.)
}

Citation: Leon, I.; Sagarna, M.;

Mora, F.; Otaduy, J.P. BIM Application

for Sustainable Teaching

Environment and Solutions in the Context of COVID-19. Sustainability 2021, 13, 4746. https://doi.org/ $10.3390 /$ su13094746

Academic Editor:

José Antonio Marín-Marín

Received: 30 March 2021

Accepted: 21 April 2021

Published: 23 April 2021

Publisher's Note: MDPI stays neutral with regard to jurisdictional claims in published maps and institutional affiliations.

Copyright: (C) 2021 by the authors. Licensee MDPI, Basel, Switzerland. This article is an open access article distributed under the terms and conditions of the Creative Commons Attribution (CC BY) license (https:// creativecommons.org/licenses/by/ $4.0 /)$.

\begin{abstract}
COVID-19 had a major impact on the 2030 Agenda for Sustainable Development, and it produced a crisis in Goal 4, which is aimed at ensuring quality education, among others. In this work, a university experience that aims to solve the challenges in this complicated context by means of BIM technology is presented. On the one hand, this study focuses on the development of teaching by means of active methodologies based on real projects through BIM models, using the latest information and communication technologies, and on the other hand, it focuses on the management of the education center by means of a virtual BIM building. This allowed for, among other things, tackling the sustainable management of the measures required to prevent contagion. These BIM models made it possible, for example, to optimize spaces while maintaining social distances between occupants, to simulate the best options for classroom ventilation, and to optimize special cleaning and disinfection resources. Students who developed their learning through these BIM virtual models were not restricted in receiving online classes; they learned to collaborate from anywhere in the world, acquiring skills that allow them to effectively face real situations that are as complicated as COVID-19.
\end{abstract}

Keywords: building information modeling (BIM); COVID-19; university; education; sustainability

\section{Introduction}

In 2015, the United Nations General Assembly adopted the 2030 Agenda for Sustainable Development [1]. This 2030 Agenda encompasses 17 Sustainable Development Goals (SDGs), an initiative for global action whose success not only depends on the actions of governments but also requires the collaboration of businesses, civil society and organizations, and of course, universities. Among the 17 SDGs, there is one in particular, Goal 4, with the objective to "ensure inclusive and equitable quality education and promote lifelong learning opportunities for all", which expressly includes the university in its target 4.3. Higher education is thus explicitly involved as a potential agent for addressing other development goals [2]. Universities therefore have a key role to play in addressing the challenges facing the planet and achieving the SDGs [3]. The practical integration of the Sustainable Development Goals remains difficult [4-6]. Although the current understanding of effective methods for integrating the 2030 Agenda from a holistic approach still has its limits, more and more experiences are emerging from universities to undertake transformative projects that broaden their approach beyond the purely pedagogical. The University of the Basque Country (UPV/EHU) is a public university that considers the 2030 Agenda and the SDGs as a structuring model [7]. For this reason, the UPV/EHU's strategic plan for 2018-2021 included the mandate to develop its own agenda for the development of the SDGs from an integral and global perspective [8]. After a process of strategic reflection, the "EHU Agenda 2030 for Sustainable Development" for 2019-2025 was created with its panel of indicators $[9,10]$. In this context of important changes involving the university environment, the COVID-19 pandemic crisis was unleashed, resulting in the temporary closure of schools and provoking a series of changes in the way teaching is provided. This 
situation has had a great impact on the quality of learning, which is linked to SDG 4. It specifies, in this Goal, that the effectiveness and guarantee of learning depends on the design of new forms of teaching that are open, inclusive, quality, egalitarian and, more than ever, accessible from any location. Thus, the inclusion of online learning opportunities was already a requirement for universities even before the pandemic [11,12]. This article presents an experience of managing the pandemic by means of BIM technology at the $\mathrm{UPV} / \mathrm{EHU}$, analyzing, on the one hand, the aspects linked to teaching, and on the other, those linked to the management of university buildings in order to ensure quality teaching even during this very complicated stage.

To put this research into context, in Spain, in March 2020, due to the number of infections and deaths caused by the COVID-19 virus, a state of emergency was declared, and the entire population was forced to confine themselves to their homes for 3 months. Education centers remained closed for 6 months, from March to September 2020, and so teaching and evaluations had to be carried out $100 \%$ online [13]. Today, one year later, there are still territorial perimeter confinements that forbid moving from one municipality to another. Consequently, due to these mobility restrictions, this research focuses on our education center in the School of Engineering at the University of the Basque Country. It should be stated that although Spain and Italy were initially the most affected countries, we can see today that COVID-19 has confined many countries to a greater or lesser extent, and as a result, their universities are suffering the same problems that were initially experienced in Spain. Therefore, this research may be of use to all those countries that are undergoing similar limitations in this context of a global pandemic. The theoretical contributions designed by means of BIM models and tested at the UPV/EHU can contribute to the development of scientific knowledge to reduce the impact of COVID-19 in general and in the educational field in particular.

Building information modelling (BIM) is a collaborative work methodology for the creation and management of constructions throughout their life cycle, reducing both the time and costs of design, execution, and operation and maintenance. Using this technology, in January 2020, two specialized field hospitals, Huoshenshan and Leishenshan, were designed, built and commissioned in record time (9-12 days) at the epicenter of COVID-19 in Wuhan, China, to address the outbreak [14]. This technology allows for the study of multiple situations linking sustainability with initiatives dedicated to preventing the spread of the virus [15]. The BIM model is a virtual building or digital twin of the real building in $3 \mathrm{D}$, and it contains all the building's information. In our case, this allows us to manage the education building efficiently and in a very sustainable way [16]. The situation generated by COVID-19, in addition to the ordinary management of buildings, requires innovative measures to protect public health. BIM models facilitate the best solutions to reduce the likelihood of COVID-19 infections indoors, such as studying the most efficient solutions for social distancing between occupants [17]. These models were also used to reduce pathogen transmission in public buildings with massive concentrations of people, such as schools, hospitals, and airports [18]. In this context of a global pandemic, there is a greater urgency for the building sector to improve the healthiness of buildings. Today, this can be managed more or less automatically by measuring various building health indicators (BHIs) through the use of existing BIM models [19]. In our research, this has allowed for, among other things, the possibility to optimize the occupancy of classrooms while maintaining safety distances, to foresee the best solutions for the ventilation of spaces, and to manage cleaning and disinfection measures in a sustainable way to avoid contagion.

COVID-19 also forced an abrupt and radical restructuring of university education. This necessitated the use of previously unused teaching resources. At present, online education has become as important as face-to-face education. Courses based on active methodologies supported by the latest information and communication technologies (ICTs) were able to make this transition with greater agility $[20,21]$. In this context of the pandemic, BIM technology is enabling a new distance learning experience by means of BIM models [22]. In our case, the teaching of BIM technology is analyzed with the use of multiple online 
platforms, which has allowed for synchronized collaboration in real time from anywhere in the world, even though students had to be confined once again in their home countries. The new resources provided by the UPV / EHU also make it possible to promote a self-paced learning culture that has resulted in an agile and simple teaching transition, which, in line with Goal 4 of the SDG, is presently, if possible, of even higher quality.

\section{Materials and Methods}

The COVID-19 pandemic affected the teaching environment for two academic years, i.e., 2019-2020 and 2020-2021. In Spain, although the central government initially proposed a common strategy for all centers [23], over time each autonomous government established guidelines for operation at the local level [24]. In these two academic years, the University of the Basque Country went through 3 stages, each of which determined different methods of action. Stage 0, or pre-COVID-19, was a 100\% face-to-face stage, which had to be abruptly interrupted by stage 1, a $100 \%$ online stage, with a 48 -h transition period, following the state of national confinement decreed on 14 March 2020 [25]. This stage 1 of teaching, continuous assessment, and online exams lasted at the University of the Basque Country until September 2020, giving way to the third stage, which is still ongoing, with $100 \%$ faceto-face teaching, but with multiple changes associated with the safety measures imposed to combat COVID-19 [26-31].

The COVID-19 crisis has had a major impact on education in general. At the UPV/EHU and at the Gipuzkoa School of Engineering (EIG) in particular, focus can be placed on two differentiated areas, namely the impact on the sustainability of the education center's resources (consumption and waste in the building linked to the new reality), and on the other hand, the impact on the education model. This latter impact, in turn, focused on 3 aspects: First, there was the adaptation of teaching to $100 \%$ virtuality in stage 1, based on online classes. Second, it is clear that certain courses which have been very well planned in the virtual classroom-based on active methodologies supported by ICTs, as in our case-are able to adapt with very little effort, even adding new resources very quickly. Third, in stage 2, there would be the development of the new $100 \%$ face-to-face teaching, prepared for dual teaching in the event of occasional confinements. At this stage, where we are today, the teaching system, the physical classroom, and the education establishment had to reinvent themselves in order to comply with social distancing and safety measures in general. Aspects related to these four issues are presented below.

This research therefore focuses on two different, interrelated areas. First, the teaching methods linked to BIM models, tested during the COVID-19 crisis, are presented. Active teaching methodologies, with project based learning (PBL), supported by advanced ICTs, were tested by the students during the 6 months when the universities were closed, and they had to receive the teaching from their homes in virtual mode. This sudden test, which was forced by the state of emergency decreed in Spain, allowed us to verify that our course, which had been perfectly planned previously in a virtual classroom, did not require any changes to the planning elaborated prior to the COVID-19 crisis. No similar experience is known; all UPV / EHU courses needed their study guides modified to adapt to the virtual modality derived from COVID-19, and in many cases, many courses had no choice but to stop carrying out tasks and even educational competences, such as group work, for example. Second, research was conducted to provide a series of information models to manage the problems caused by the COVID-19 crisis in education centers more sustainably. The BIM models were designed, and different virtual elements were parameterized; these were tested to see how well they worked, with simulations carried out, and finally, different measurements were monitored to verify that these models enabled the processes studied to be optimized. For this second area, which focus on the management of the education center in times of COVID-19, the research made it possible to contribute to the development of scientific knowledge in three fields to prevent contagion: first, an optimization of classroom occupancy, complying with the established safety distances; second, the optimization of 
disinfection and waste management; and finally, a study of the most appropriate natural ventilation to avoid the concentration of COVID-19 aerosols.

This applied research with BIM models is based on the scientific methodology referred to as design science research (DSR). DSR focuses on solving practical problems with theoretical relevance, providing theoretical contributions within the solution, and producing artefacts as an output [32]. Simon [33] posited that DSR is concerned with devising and evaluating manmade artefacts that seem to resolve real-world problems. An artefact is created to resolve a practical problem, but this artefact needs to be empirically evaluated. If problems are related to physical objects, the solutions can be represented as plans, 3D models, or engineering drawings. Problems related to actions can be represented with flowcharts and software solutions [30]. Design theory can include the other forms of design knowledge: constructs, models, methods, and instantiations that convey knowledge [34].

\subsection{Virtual Classroom}

The availability of appropriate resources is a basic requirement for the success of quality virtual teaching accessible to all. Although in stage 0 , most universities already had platforms known as "Aula Virtual" (translated to "virtual classroom" in English), their use was not compulsory, and in many cases these platforms functioned as a mere repository for students, used for posting notes and assignments and for collecting projects. On reaching stage 1, i.e., the $100 \%$ virtual stage, it became clear that many courses that had the virtual classroom resource were not fully prepared to develop the required virtuality effectively and efficiently. It became clear that the most important thing was not to have a virtual platform but to organize the resources contained within them at the service of an exhaustive planning of the course.

In some cases, in stage 1, the virtual class was understood as a way to give the face-toface class in online format by means of different resources such as Zoom, Teams, Google, or Jitsi Meet, etc. In many cases, this is reminiscent of traditional education, where the teacher, who is the axis of the learning process, simply gives a lecture to the students without adapting the content, planning, or methodology. This generated added stress for the students in the first instance and subsequently for the teaching staff when they had to assess the students with a methodological system that was not prepared for this change.

In our particular case, the "BIM Technology" course was developed through active teaching methodologies, supported by innovative information and communication technologies (ICT), using platforms or spaces for the development of a virtual flow and software that focus on providing a relationship between onsite and offsite work, enabling a centralized record of all teaching activity to be kept. Due to the collaborative work that our students develop in the subject, these resources were grouped into three main platforms. The first is a virtual repository of information in the cloud, a version of Nextcloud customized by the UPV/EHU, called "ehubox" (https:/ / ehubox.ehu.eus/login accessed on 22 April 2021), which enables a flow of information of up to 50 GB and makes it possible to synchronize all types of files (Word, Excel, etc.), although it does not allow simultaneous work on the same 3D BIM model to be synchronized in real time. For this purpose, there is a second virtual space accessible, used exclusively for the collaborative 3D modelling work, with greater synchronization, allowing for the exchange of models, BIM families, and information, called Gordetalde (https:/ / www.ehu.eus/gordetalde/php/login.php?lang=es accessed on 22 April 2021). It permits simultaneous collaborative work in real time from anywhere in the world using VPN (virtual private network) technology. The third is the corporate virtual classroom, a version of Moodle configured and customized by the UPV/EHU, called eGela, (https:/ / egela.ehu.eus/login/index.php accessed on 22 April 2021). This platform contains all the course material, allows for the exchange of files up to $20 \mathrm{MB}$, serves as a record of all teaching activity, and centralizes the evidence of the students' continuous assessment. In our case, it became the epicenter of the course, as it is the link to all platforms and software, as well as the basis of all virtual activity. 
The preliminary global programming of the course in this third platform (i.e., the corporate virtual classroom), both in terms of content and its control and management, is an essential condition for success in any circumstance. In our case, it allowed us to move from face-to-face teaching to 100\% virtual teaching at the height of the 2019-2020 academic year in a natural, seamless way, and without any kind of disruption or anomaly. This powerful, meticulous, complete and ad hoc initial preprogramming is mimicked with the workflow in BIM management processes, i.e., the subject matter of the course. From the beginning of the course, students know the time schedule, the documentation and contributions, their tasks, deliverables, as well as the different assessment rubrics specific to each of them, and so the learning process and objectives are not an uncertainty, thus allowing those involved to clarify and to keep their training and qualification process up to date. The theoretical content flows automatically in the virtual classroom and is accessible in the respective weeks. The same applies to the different deliverables, scheduled in the same way in terms of date and content to be provided.

In stage 1 of severe confinement, where teaching and assessment had to be $100 \%$ online, the UPV /EHU made a new resource for teaching the class online available, i.e., Blackboard Collaborate Ultra (BBC), an online remote monitoring classroom (https:/ / www. ehu.eus/bilerak accessed on 22 April 2021). Although the market has made it possible to learn about and use different resources for the development of online classes, in most cases they work with a link that can be sent by e-mail or posted on a teaching platform. One of the great advantages of BBC is that it can be generated as its own resource in the course's virtual classroom, eGela. As it is implemented as another resource, it allows for virtual teaching in real time, with the work groups continuing their activity as usual (Figure 1).

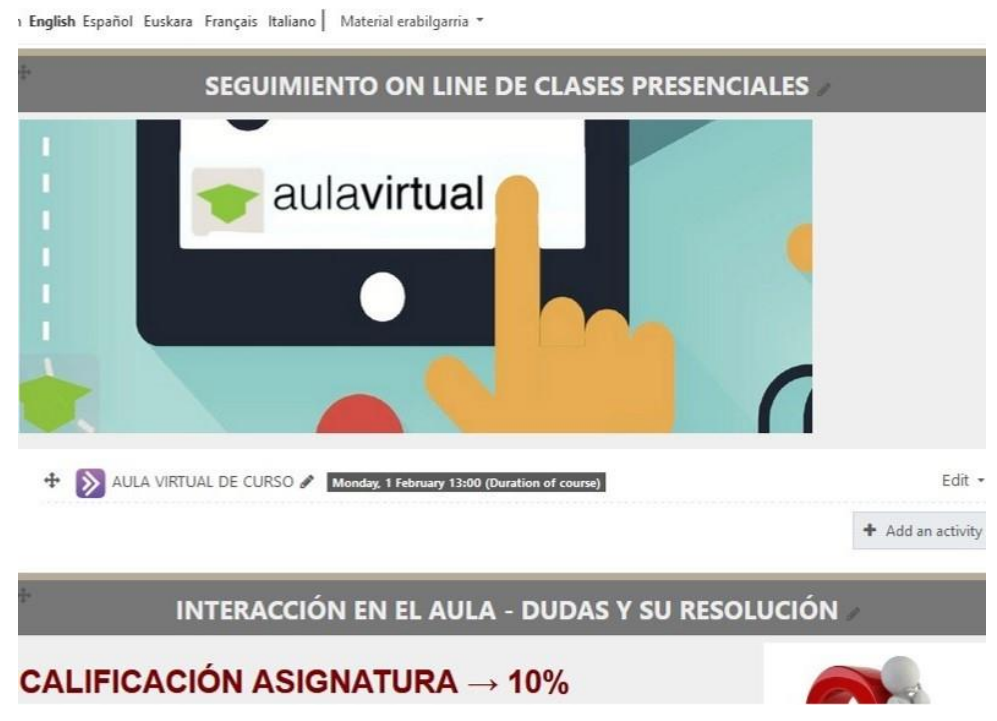

(a)

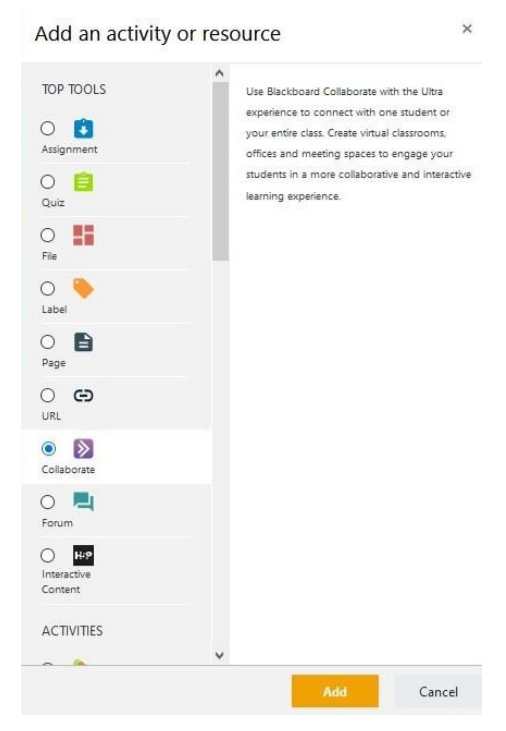

(b)

Figure 1. Aspect of the virtual classroom of the BIM Technology course in eGela: (a) Partial view of the planning of the different sections, button to add new resources, and aspect of the BBC resource; (b) pop-up window to add the BBC online classroom within Moodle for eGela.

Another very positive aspect for teaching is that it allows online classes to be recorded in various ways. You can opt for a direct download mode in eGela, or for an external download, which, after appropriate editing, allows you to upload the videos to platforms such as YouTube, with the videos embedded in thumbnail format in eGela without having to access YouTube externally. The videos are uploaded in hidden mode, to be played only by selected students, allowing them to learn at their own pace, which is very positively valued (Figure 2). 


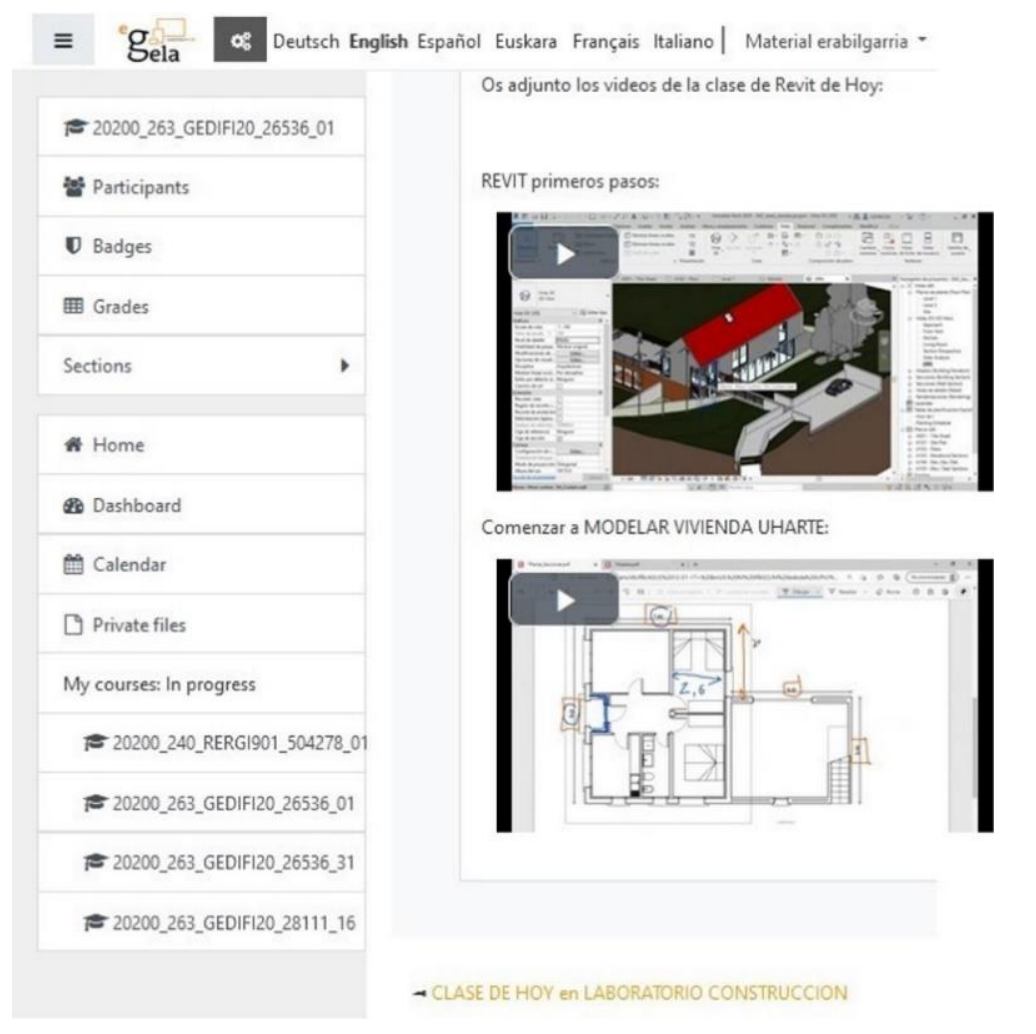

Figure 2. Miniature image of embedded YouTube videos posted on eGela.

In the same way, this resource also enabled us to monitor each student personally and individually, according to their needs and demands, allowing us to further improve the course. It is also a resource with a permanent record that remains as evidence, storing the entire traceability of the virtual teaching development. This therefore makes it possible to evaluate the evolution process of this virtual teaching, even in severe confinement, where not even the inspection service was able to audit the development and quality of the classes.

It should be pointed out that the virtual classroom has the potential of greater interactivity if it were accompanied by a virtual 3D model, where students could interact with others through their own avatar; such a model may even allow for virtual interpersonal actions, which are prohibited in the real environment due to safety issues in relation to COVID-19. The BIM models generated in the subject can serve as a more immediate virtual environment and can simulate the physical classroom.

\subsection{Physical Classroom}

Since September 2020, the impact of COVID-19 on the physical classroom is considered as stage 2, when the Basque Government and the EHU decided to offer 100\% face-to-face teaching, provided there is compliance with the necessary safety measures, which can be simplified as follows: social distancing, intensified cleaning, and compulsory face masks.

This affects university centers such as the EIG in several important respects. In terms of social distancing, this required studying and marking movement paths via different signs and flow arrows so that there are no crossings of people, thus preserving distances of $2 \mathrm{~m}$ in transition spaces and $1.5 \mathrm{~m}$ in permanent positions in the classrooms. This required an exhaustive study of the buildings. Fixed stickers were placed on the floors indicating the directions of movement, the minimum distances in transit areas, and where queues are generated. Multiple signs were installed to provide information and to establish staircases for just going up or down, generating new flows and habits. In addition, the number of students in the classrooms has been limited, where places in the respective seats fixed to the floor are made unavailable. The fixed seating system was further challenged (Figure 3a), and it proved to be unsustainable in times of COVID-19 in many cases. The reduction in 
class capacity has made it necessary to set up a second classroom, known as the "mirror classroom", so that some of the students can follow the class live from this other space by means of projections via a projector and a screen. It was necessary to make a significant economic investment in complex systems consisting of cameras, screens, and audio capturetransmission systems in order to be able to reproduce the class instantaneously in these two classrooms, without losing the possibility of interaction between the students and the teaching staff (Figure 3b).

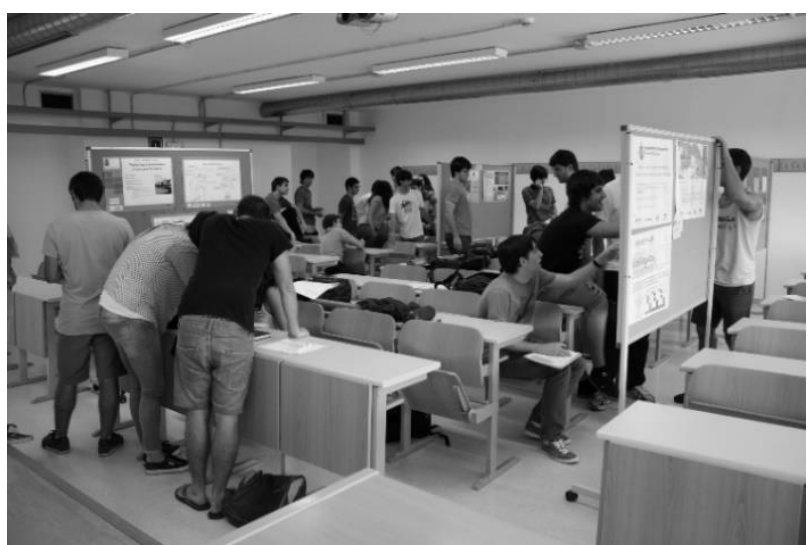

(a)

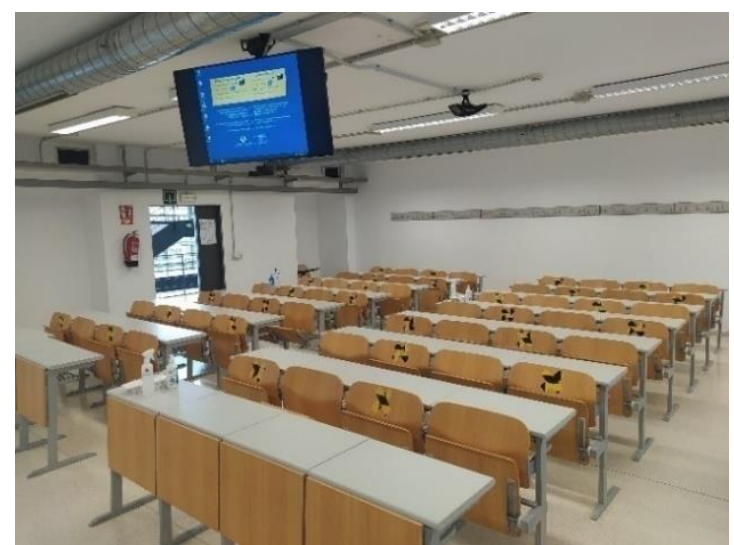

(b)

Figure 3. (a) The classroom with fixed tables in the pre-COVID-19 phase; (b) The classroom with fixed tables in the COVID-19 phase, along with reduction of seats and new audiovisual systems for the operation of the "mirror classroom".

In computer classrooms with mobile furniture, the use of fixed computers causes the same problems as in classrooms with fixed furniture. Maintaining the $1.5 \mathrm{~m}$ distance means, in many cases such as the one in the picture, a 33\% reduction in the number of available workstations, which greatly limits the efficiency of the classroom (Figure 4).

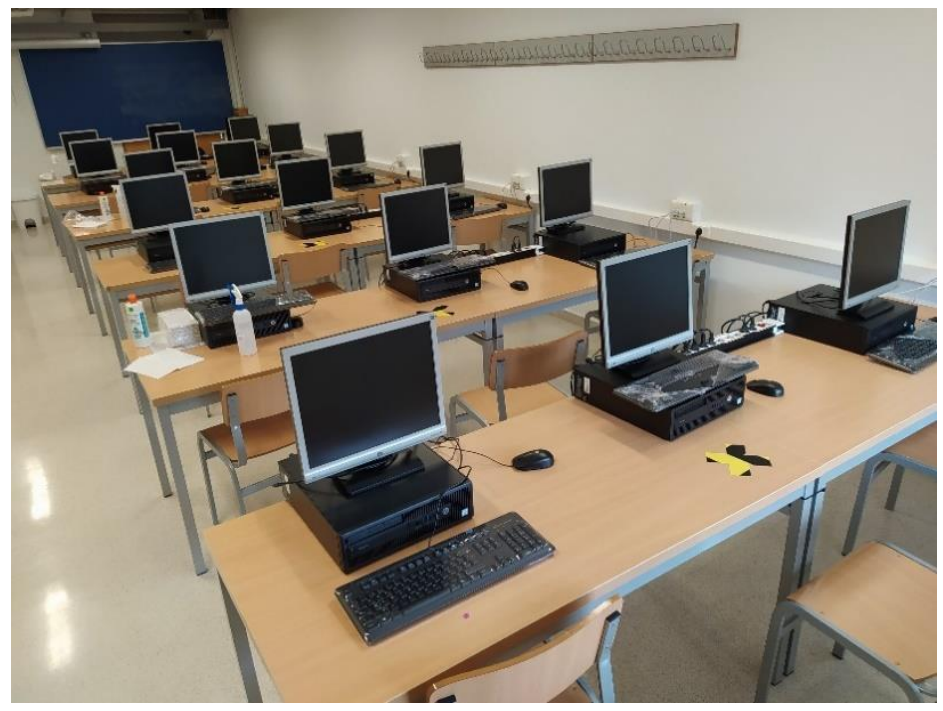

Figure 4. Fixed computer classroom with a significant reduction in workstations.

In the whole building, only our laboratory, which was designed for the BIM subject with mobile tables and laptops, was able to increase the number of workstations for students while complying with the established social distancing measures. BIM models make it possible to study the most efficient solutions to adapt to the new distance requirements, through generative design and the parameterization of requirements. 
Another aspect that substantially changed people's habits is the need to intensify cleanliness. The EIG made a great effort, and this resulted in a powerful system that requires exhaustive management. The provision of a multitude of fixed and portable hydrogel dispensers for cleaning hands, spray bottles for cleaning furniture and for cleaning computer equipment and peripherals, paper wipes, and new specific containers for the waste generated in this cleaning process, requires significant investment and constant management. These measures, adopted for the sake of safety, are in many cases at odds with sustainability. Therefore, the management of these education centers with BIM models can end up being much more efficient and certainly more sustainable.

\subsection{Sustainability against COVID-19}

In the initial stage of severe confinement decreed by the COVID-19 crisis, there was an awareness that nature was given an opportunity to be less disturbed by human activity than usual. It was a time of reduced emissions and therefore a time of environmental sustainability [35]. However, in stage 2 of face-to-face teaching, sustainability has suffered in universities, and many of the initiatives for SDGs became limited. Although education continues to be of high quality, it was necessary to invest a lot of money in new resources: screens, cameras and audio systems for mirror classrooms, dual teaching, etc. Although the investment in posters, signage, and vending machines for cleaning products is smaller, they require ongoing management and a constant outlay in terms of cleaning products in particular. Social distancing requires the use of more space with fewer people, thus increasing lighting consumption among other things. The need for ventilation to prevent aerosols [36] also led to an increase in heating consumption [37], and this required, at least in the EIG, an investment in the modification of the fittings of some windows to convert them into tilt-and-turn windows.

The impact of COVID-19 on waste management is also significant and goes against the environmental sustainability initiatives that the EIG has been developing, particularly in the area of having a strong management of waste for recycling. At the beginning of stage 2 , selective waste collection was substantially reduced due to uncertainty about the possibility of virus transmission through waste stored for recycling. From the outset, new bins were installed for waste that was more likely to come into contact with the virus, such as wipes used for cleaning hands, furniture, and equipment. At the beginning, these bins collected almost all the waste, but over time the separate collection system has been restored. From September 2020 to date, separate collection points were added, taking into account that the EIG has no data that link the separate recycling system with direct infections. In February 2021, new, larger bins for selective recycling were added.

Sustainable building management is one of the great potentials of the BIM methodology. In fact, there is a BIM dimension [38,39], referred to as 6D, which allows for modelling, simulating, and managing the energy efficiency of buildings throughout their life cycle (LC). BIM dimension 7D, called facility management (FM), focuses on the management of the asset after the end of construction. This enables building operators to manage maintenance and service based on BIM [40,41]. This dimension becomes even more important in the management of business-related aspects in this COVID-19 era. Waste management, the intensification of the cleaning system translated into replenishment and purchasing management, the study of air renewal systems linked to higher heating consumption, and window replacement can all be managed from a BIM model. At the moment, the EIG has a BIM model that was generated to investigate and simulate FM possibilities for increased sustainability (Figure 5). 


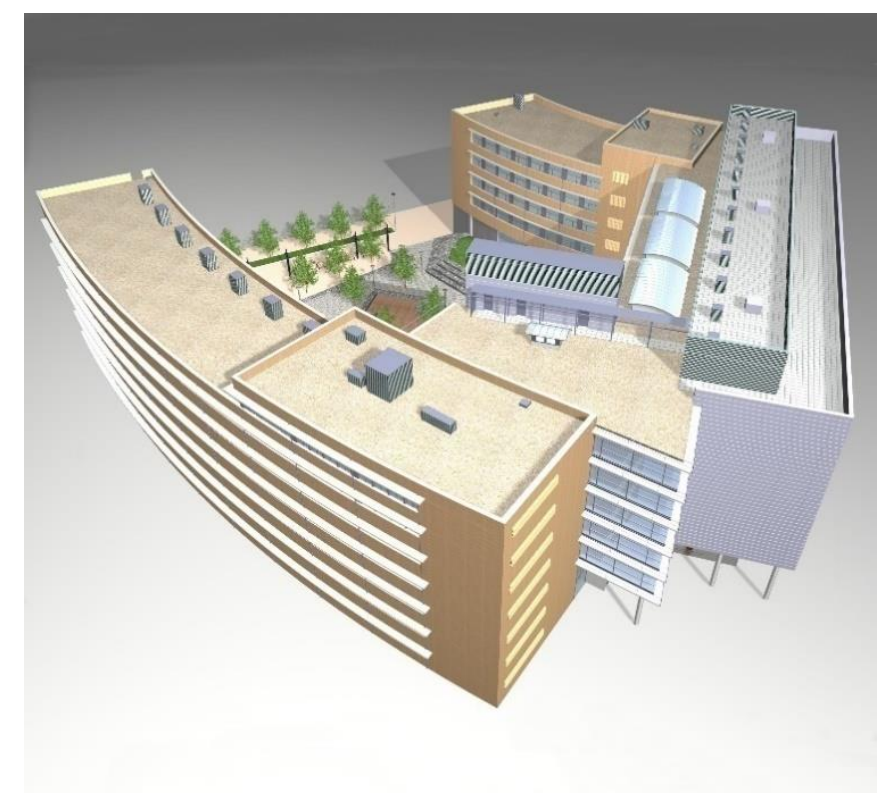

Figure 5. The Engineering School of Gipuzkoa (EIG) has a BIM model.

In order to obtain a BIM model with high precision, the EIG was scanned with a terrestrial laser scanner. A high definition 3D scanner, model P40 from Leica Geosystems, was used with a scanning speed of 1 million points per second with a range of up to $270 \mathrm{~m}$ (Figure 6a). The large dimensions of the building required an exhaustive scanning plan, which made it possible to generate multiple point clouds of the building. The generated clouds were processed by Leica's Cyclone REGISTER and Autodesk's ReCap ${ }^{\mathrm{TM}}$ Pro software, which condensed the result into 3 clouds in .rcp format. These 3 clouds were then imported into Autodesk's Revit software, version 2020, to generate the BIM model of the building. In the 3D model, all the management aspects mentioned above were included, where we estimated a model development level that takes into account, among other aspects, the different waste containers and the different cleaning product dispensers (Figure 6b).

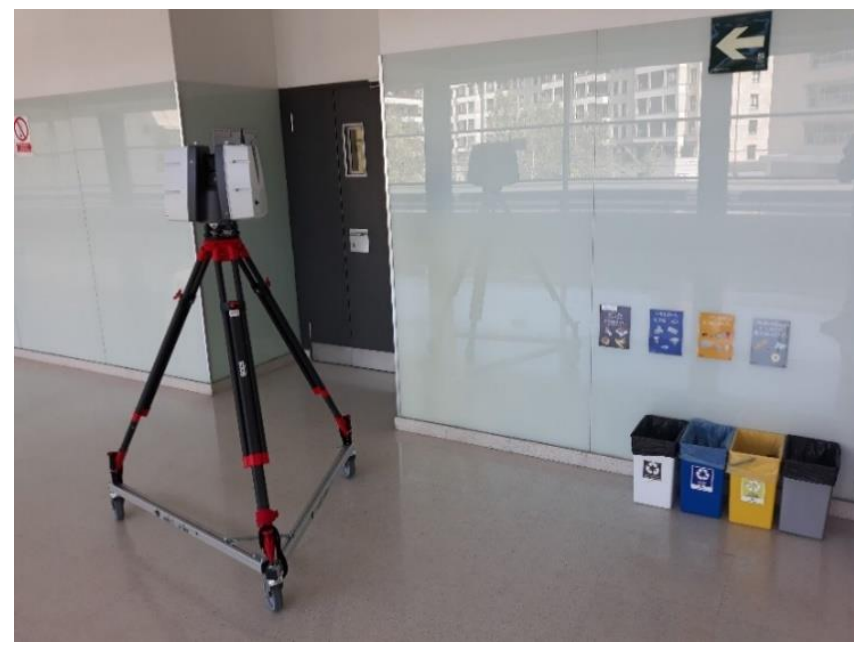

(a)

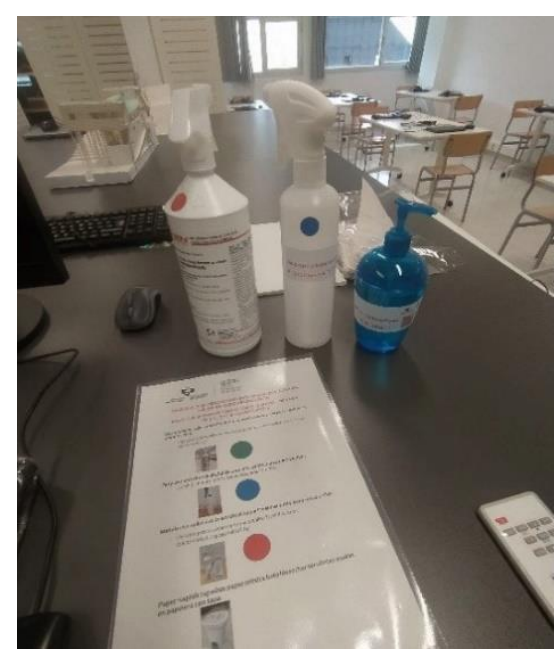

(b)

Figure 6. (a) 3D scan of the EIG in accordance with the separate waste recycling system; (b) location of the wipes and mobile dispensers for the 3 types of cleaning products that were installed throughout the center, with a sign explaining their specific use. Image of one of the points in the construction laboratory. 


\subsection{BIM and Active Teaching Methodologies}

In Spain, since 26 July 2019, in compliance with the European Directive 2014/24/EU on public procurement [42], public administrations started to require BIM for both building and infrastructure public tenders [43]. This necessitated preparing students who are pursuing a university degree that has a link with the AEC (architecture, engineering, and construction) industry sector, which consists of separate players who work together to bring a project to fruition [44]. The BIM methodology allows the AEC industry to be more efficient, and the application of this methodology in the classroom brings students closer to a professional reality committed to sustainability [45].

The BIM Technology course of the EIG at the UPV/EHU is a course part of the degree program that bases its learning on active methodologies. It gradually promotes cooperative work throughout the development of the course while focusing on student self-learning, either independently or in cooperation with others, allowing students to develop activities guided by the teacher that are closely linked to the professional reality and to achieve the objectives initially set. Active methodologies promote the change of the teacher figure, to become a guide and orientator, with students as the sole protagonists of their own learning process [46].

The course is based on PBL [47], with students in collaborative work groups who develop two different projects throughout the year. It is the students who look for solutions to the problems that arise, generate questions, debate ideas, design plans, research data, present their results to others and, in short, generate a better final product on very real issues that are related to the future employment framework, once they graduate [48].

BIM technology is a completely practical subject with some very specific, automatically programmed, theoretical contributions, which, in some cases, are presented to the students by external experts from the AEC industry (Figure 7a). Students are confronted with the work process and workflows in BIM processes, similar to those they develop later in their professional lives. Each component of the course-as in the assignment of roles and responsibilities; the previous constructive research; the development of architectural, structural, and MEP (mechanical, electrical, and plumbing) models; the collaborative work, either face-to-face or online; the scheduled deliverables; and the interaction in the virtual classroom through the resolution of doubts or questions that they themselves resolve and manage-makes the learning framework fully active, autonomous and responsible. The skill of collaborative and multidisciplinary work, as the basis of active methodologies [49], is implemented and adapted in a natural way to BIM workflows, which form part of the course subject matter. The University of the Basque Country's corporate ICT resources are available to plan and develop the course and its content. The resources used allow for unified communications through the integration of telecommunications and computers, as well as the necessary software. The aforementioned storage systems, together with the audiovisual systems, enable students to access, store, transmit, and manage information. These aforementioned virtual spaces allow, through the corporate VPN connection, the possibility of access, work, and communication from anywhere in the world and at any time (Figure $7 \mathrm{~b}$ ), and so the course does not distinguish between face-to-face and online work. This allowed us to adapt to the restrictions due to the COVID-19 pandemic, thus maintaining the normal rhythm of the course without interruptions. 


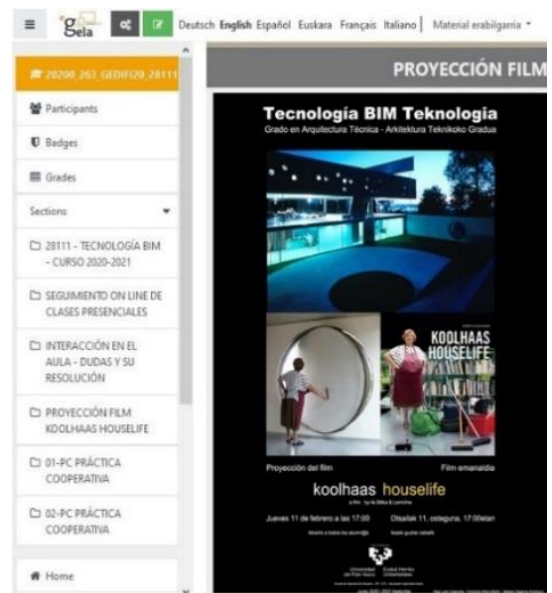

(a)

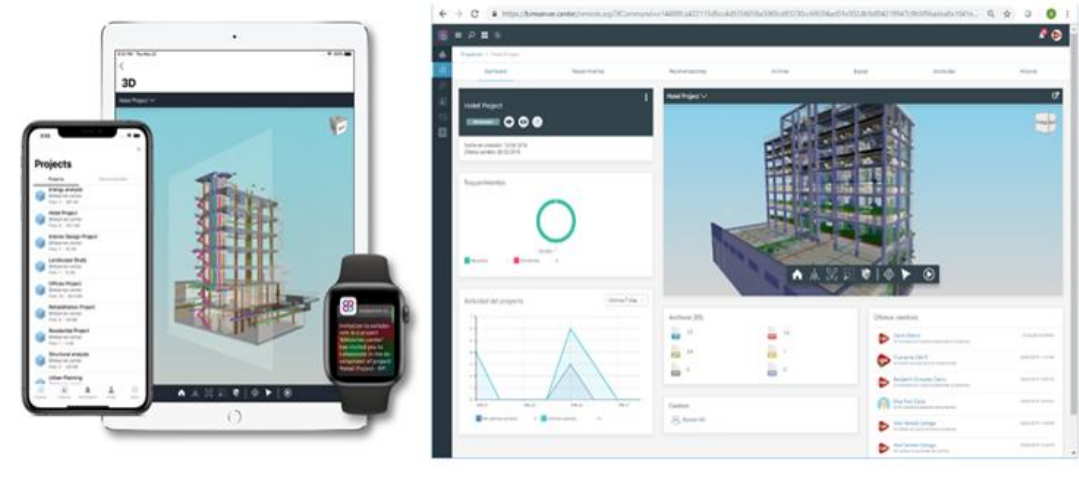

(b)

Figure 7. (a) Planning in eGela of a technical workshop to develop the PC-01 exercise; (b) platforms and servers used that permit synchronizing 3D models from any location (BIMserver.center Education).

Two collaborative PBL projects were planned for each course, i.e., 01-PC and 02-PC. Each working group consisted of three people. The initial working groups for the first PBL, 01-PC, were formed at the beginning of the course, either by the teacher, by drawing lots, or by affinity among the students. In the following PBL, 02-PC, they worked in different groups; this encourages rotation and new social experiences that allow for new learning scenarios to be constructed, and this also intensifies the habits of discussion and collaboration. The decision on grouping in this second activity was made voluntarily by the students. Once the working groups were configured, the members managed the assignment of the respective roles in a consensual manner, depending on the tasks to be carried out.

The subject is continuously assessed, with no exams or final tests. Each PBL is subdivided into weekly deliverables with their respective grading percentage, specified both in the heading and in the virtual grader; the assessment and grading process is progressive, gradual, and weekly, and students are aware of their progress at all times. In the virtual classroom, each group delivers a document report each week that compiles and justifies the tasks carried out in that period of time. The teacher verifies its content with the supervision of the local models on the server, grading it through a digital assessment rubric with specific indicators known beforehand by the students (Figure 8a). The grade is fed back to each member of the group with the corrected document. This evolutionary, gradual, regular grading and weekly feedback process allows each group to see how it is doing in terms of the learning objectives set and to make the decisions it deems appropriate for improvement.

Once the work period of each of the two scheduled PBL projects is over, each of the group members takes stock of the quality of their work and that of their 2 companions who would carry out their co-assessment by completing and sending the "cooperative self-appraisal" self-completing document to the respective section of the virtual classroom in a discretionary manner (Figure $8 \mathrm{~b}$ ). Through this document as well as its items and assessment indicators, we obtain the ICF (individual co-assessment factor), which is multiplied by the group's overall grade and particularized into an individual grade [50]. These individual particularizations of the group grading are carried out when each of the two tasks are completed, so as to not jeopardize the work process and the internal relations of its members. As Sambell, McDowell, and Brown stated, the skills of self-, peer-, and co-assessment are effective in the development of lifelong learning and in the development of individual autonomy [51]. 


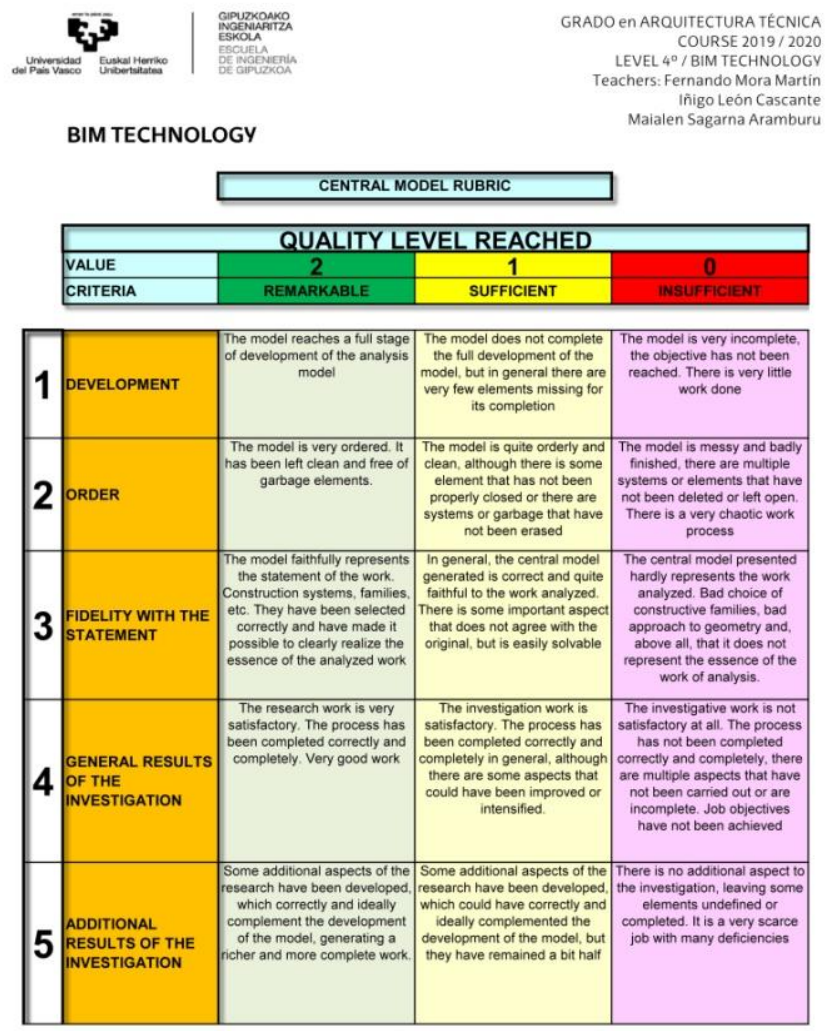

(a)

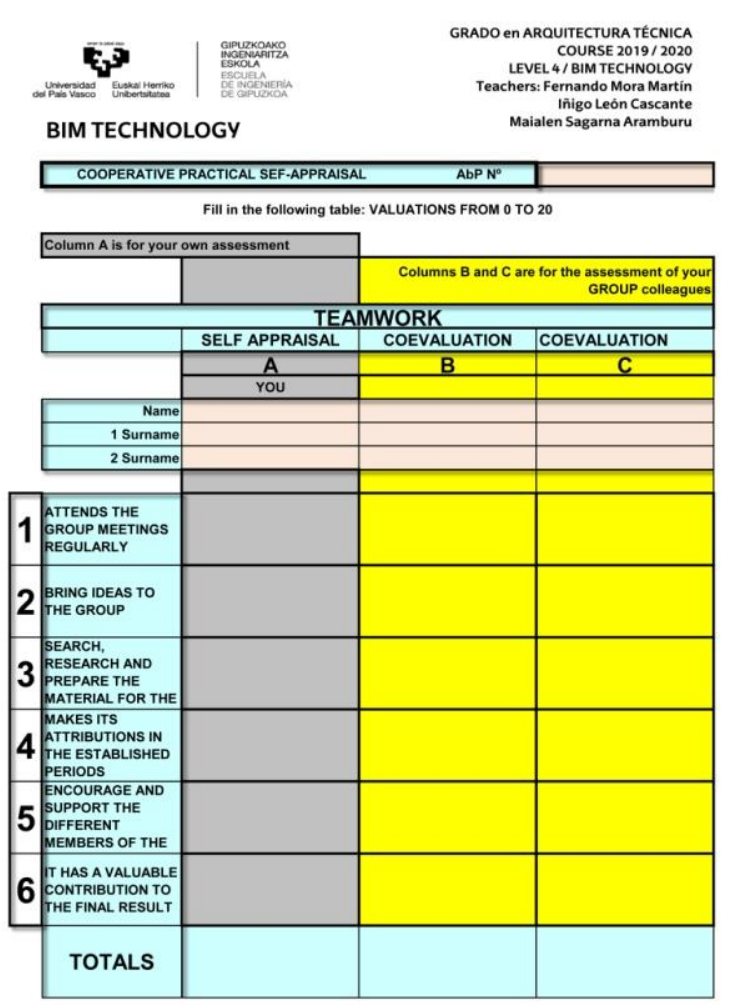

(b)

Figure 8. (a) Grading rubric particularized to the central model, (b) cooperative self-appraisal, which is self-completed by each student for each collaborative PBL project.

\section{Results}

The results obtained in the different areas described in the Methodology section are presented. As these are the results obtained in the management of problems by means of the BIM models, this section shows different images of the results accompanied by concise and precise descriptions. The results are presented in two blocks. The first shows the results linked to the effect of COVID-19 on the education center, starting with the management of changes in the physical environment, and then the issues affecting sustainability management (consumption, waste, cleanliness, air quality). The second subsection presents the results of the teaching proposal linked to BIM models, which very effectively overcame the situation produced by COVID-19 in both stages 1 and 2 (as described in Section 2 of this article).

\subsection{Sustainability in the Context of COVID-19 through BIM Models}

A BIM model of the EIG education center was created based on the point clouds obtained from the 3D laser scanning (Figure 9). This BIM model allows for a more sustainable development of the building in many areas (general maintenance, repairs, classroom management, etc.), but it can also be a key element for the management of the new problems and activities that emerged in the COVID-19 context. 


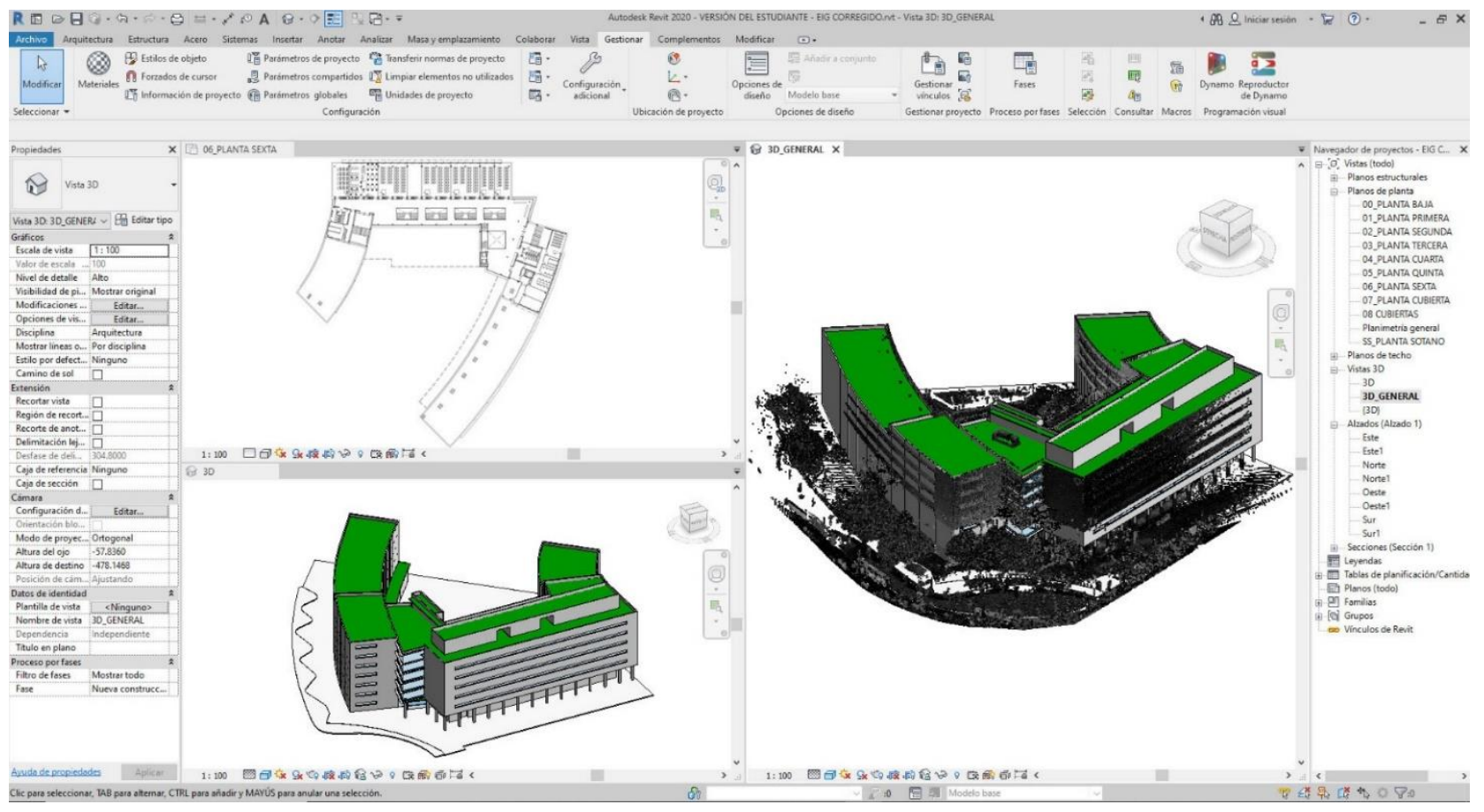

(a)

(b)

Figure 9. (a) The model allows for the generation of all types of views and plans of the building; (b) BIM model built virtually using the 3 geolocated point clouds linked to the model as a highly precise reference.

After processing the data with the software discussed in Section 2.3, the .rcp files were linked to an architectural model of the building carried out with Autodesk Revit 2021 software. The BIM model of the building is a virtual model of the real building, where the concrete structure, the façade enclosures, the interior walls, the roofs, the furniture, etc., were built virtually [52]. Any element that is in the real building can have its digital twin with all the geometric information geolocated, and it can also have all the nongeometric information related to its characteristics, such as the materials that comprise it, its physical and chemical properties, etc. [53].

In addition, all kinds of conditions and parameters can be associated so that the model can provide warnings to the people responsible for maintenance in the event that any measurement is outside the most appropriate range. This subsection shows the results of the use of the BIM model in the COVID-19 context for the following uses: first, in the simulation of the best options for adapting spaces and furniture to ensure the social distancing required by the authorities; second, in the more sustainable management of the specific cleaning system required to avoid the transmission of the virus, which is linked to an inventory of the most efficient waste management possible; and finally, in the control of the ventilation of the building spaces in trying to avoid the effect of COVID-19 aerosols.

\subsubsection{New Requirements in the Physical Environment}

The UPV/EHU university's decision to provide 100\% face-to-face classes in stage 2 had a major impact on the use of the building in general. Complying with the 1.5 and 2 meter spacing measures has conditioned the use of the physical spaces in both the classrooms and skills labs. In most cases, it was necessary to reduce the number of people in the interior spaces, thus needing to double the number of classrooms in order to be able to accommodate all the students in some subjects. Using two classrooms for one class means an investment in two audiovisual systems so the students in the second classroom, i.e., the mirror classroom, could follow the class, in turn doubling the energy consumption for lighting. The BIM Technology course, with a teaching system based on active methodologies, operated in a classroom with mobile tables and laptops, which 
allowed us to adapt to any activity with great ease and allowed students great versatility to carry out all kinds of tasks. The tables can be grouped together and can be easily folded for us to use the entire space for brainstorming activities or for studying projects with virtual reality. This classroom format made it possible to adapt to the conditions of COVID-19 very easily, making it the most sustainable teaching space in the school.

The EIG building was modelled at a LOD200 [54] development level, and inside, the BIM classroom was virtually built at the LOD500 "as built" level [55] (Figure 10a). The virtual model contains all the elements of the real classroom. It is a digital twin in which the elements affected by the anti-COVID-19 measures were studied in order to obtain the most out of the use of the classroom, with the aim for us to be even more sustainable in these difficult times. This is much easier and more effective through the generative design that integrated the latest version of Revit 2021 modelling software (Figure 10b).

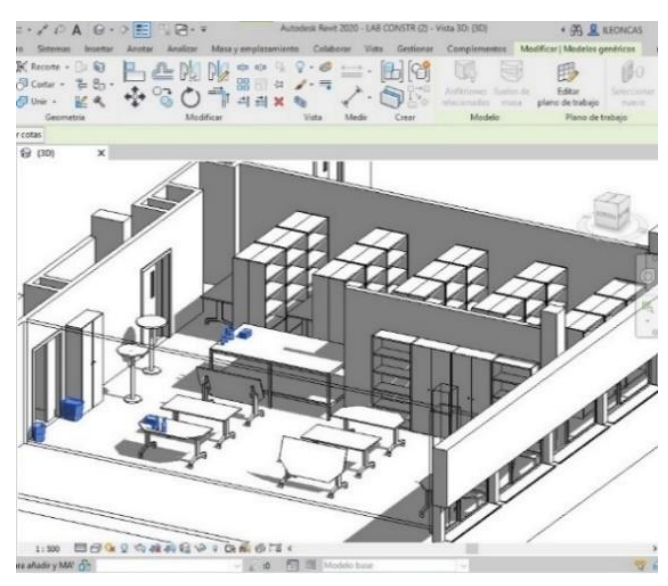

(a)

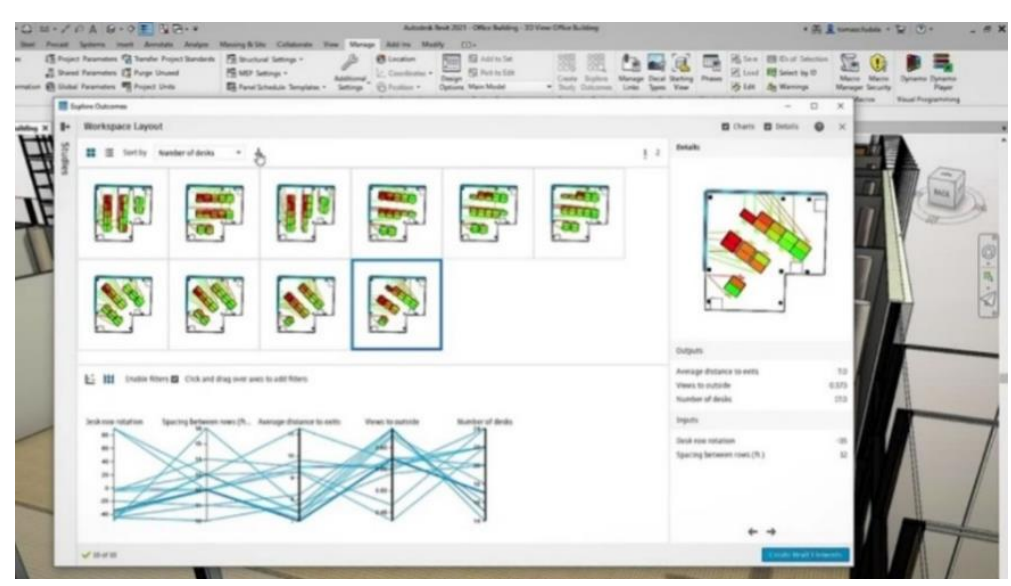

(b)

Figure 10. (a) Virtual model, or digital twin of the BIM classroom; (b) study of infinite solutions for the most efficient placement of tables in a space through generative design in Autodesk Revit 2021.

Generative design makes it possible to discover countless possible permutations of a solution to find the best option, allowing for studying thousands or even millions of design options in a very short period of time, where it is possible to analyze in each case what works and what does not $[56,57]$. The process generates options through algorithmic definitions, which a human hand would find difficult to create alone in order to arrive at an effective design. Multiple options for the location of the desks in the classroom were studied, as we aimed to fulfil two design criteria, i.e., to maintain the interpersonal distance of $1.5 \mathrm{~m}$ and to try not to reduce the number of seats for the class that was already predetermined before the COVID-19 crisis. This study resulted in several options that meet these requirements, but two were selected, one for group work and one for individual work, which have been tested in the real physical classroom (Figure 11).

The classroom had a capacity for 25 students prior to COVID-19, and it was possible to implement an option where the number of people who can follow the class increases from 25 students to 28 (Table 1 ). 


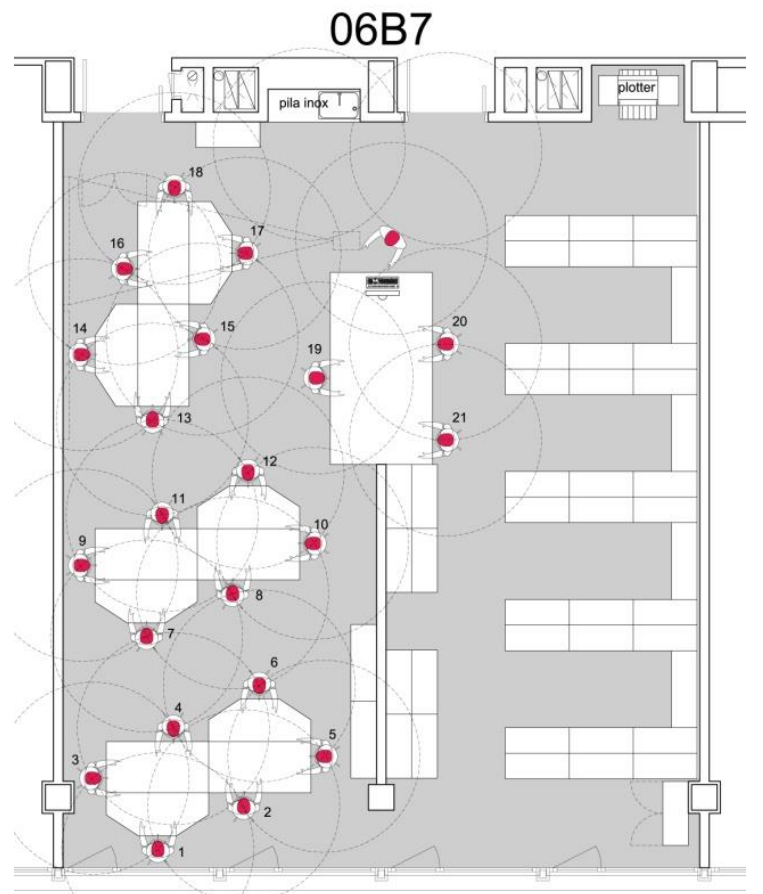

(a)

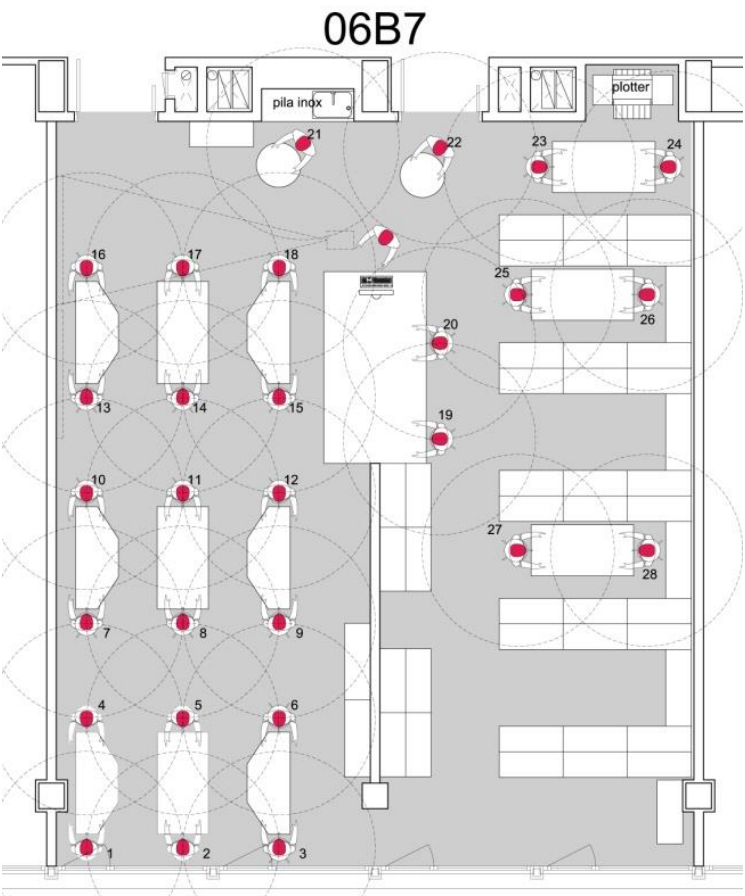

(b)

Figure 11. Solutions to meet the 1.5 meter spacing requirement: (a) layout for possible collaborative group work; (b) layout for individual work development.

Table 1. Modification of the occupancy of some representative classrooms in the COVID-19 context.

\begin{tabular}{cccc}
\hline Classroom & Previous Occupancy & COVID-19 Occupancy & Modification \% \\
\hline Theory classroom with fixed desks & 36 & 18 & $-50 \%$ \\
\hline $\begin{array}{c}\text { Classroom } 4.1 \text { with fixed } \\
\text { computers }\end{array}$ & 25 & 18 & $-28 \%$ \\
\hline Graphic expression classroom & 26 & 23 & $-13 \%$ \\
\hline Industrial organization classroom & 26 & 25 & $-3.8 \%$ \\
\hline BIM classroom & 25 & 28 & $+12 \%$ \\
\hline
\end{tabular}

In order to carry out this study, virtual models of the furniture were created, each containing the information necessary to study the best option. They resulted in 4 series of parametric desk families that allow the classroom layout to be optimized. There are two desk models, one straight and one chamfered, which have two position variants. They can be placed ready to work, or they can be folded to free up the classroom if necessary for certain tasks, e.g., for brainstorming and for virtual or augmented reality activities using specialized glasses (Figure 12).

After studying the best options for the location of desks, the BIM classroom is the only one in the building that was able to increase the number of seats for students by $12 \%$, complying, at the same time, with COVID-19 prevention measures. 


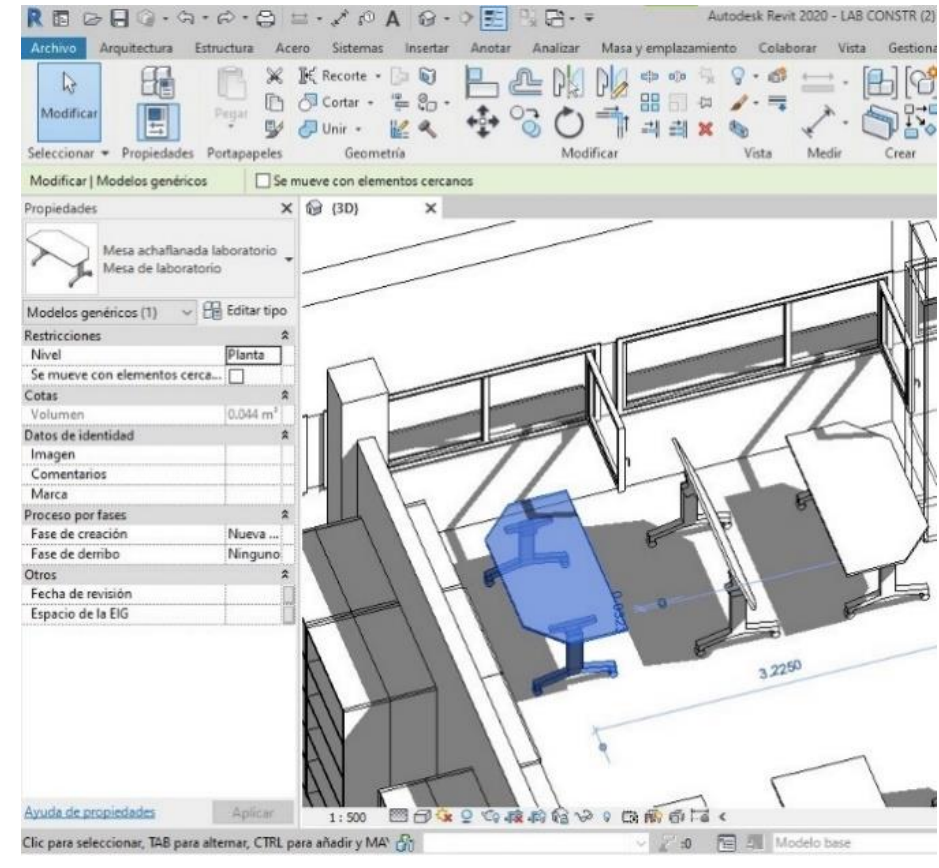

(a)

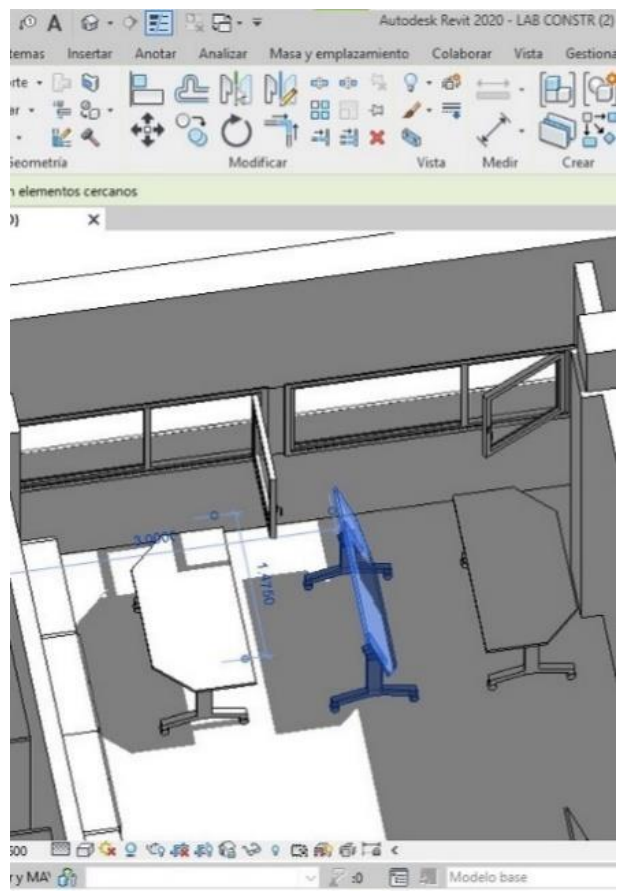

(b)

Figure 12. (a) Parametric desk family ready to work; (b) folded desk family.

\subsubsection{Cleaning and Waste Management}

Another issue that has a considerable impact on the management of the education building is the unique cleaning system to prevent contagion in the COVID-19 context, which has a direct impact on the waste management of the school.

As mentioned above, the EIG decided to implement a very effective system consisting of disposable paper wipes and 3 cleaning products for different uses. For cleaning hands, hydrogel dispensers were marked with a green dot; for cleaning furniture and surfaces, sprays were marked with a red dot; and for disinfecting computer equipment or devices (controls for switching on equipment, keyboard, mouse, screen, etc.), another series of sprays had a blue code or dot. In most cases, the 4 disinfectant products were deposited in portable containers, but there are several points with fixed dispensers on the wall. In total, throughout the building, including classrooms, laboratories, toilets, and other spaces, there may be more than 200 cleaning points requiring efficient management and considerable expense (Table 2).

Table 2. Evolution of consumption of disinfection and cleaning products in the building.

\begin{tabular}{ccc}
\hline Product & Terms (2020-2021) & Consumption per Week \\
\hline \multirow{2}{*}{ Hand hydrogel (green) } & September-November & $15 \mathrm{~L}$ \\
& December-February & $12.5 \mathrm{~L}$ \\
\hline \multirow{2}{*}{ Furniture disinfectant (red) } & September-November & $20 \mathrm{~L}$ \\
& December-February & $12.5 \mathrm{~L}$ \\
\hline \multirow{2}{*}{ Equipment disinfectant (Blue) } & September-November & $10 \mathrm{~L}$ \\
& December-February & $5 \mathrm{~L}$ \\
\hline \multirow{2}{*}{ Paper wipes } & September-November & 10 boxes \\
& December-February & 3 boxes \\
\hline
\end{tabular}

The replenishment of these points and the management of purchases require a major effort to ensure that there is no shortage of products at any time. In order to optimize 
the management of the 4 products, the 4 virtual models of the products were created using the same color code that they were assigned with (i.e., green, red, blue). They were parameterized with 3 status options, i.e., "empty", "full", or "half-full", and were positioned in the classroom in their real geolocated position. With these digital twins, the maintenance service team can have a record of each cleaning point in the actual BIM model and can visualize the consumption on their own mobile phone. With a simple click on the screen, the inspection and replenishment tasks can be optimized, ensuring that there is never a shortage of product. All of this can be done in a very efficient manner. Product purchasing management can also be much more tightly managed and sustainable in each case. Planning tables can be automatically extracted, using different classification parameters, by date of inspection, type of product, location in the building, and consumption status, among other options. In addition, a historical record would be kept of each space in the building to see whether there are anomalies in consumption due to excess consumption, or whether there is a classroom where staff are not using the cleaning products, a fact that could be creating a situation of risk of contagion. All kinds of statistics could be kept, such as consumption in classrooms in relation to the number of students (Figure 13).
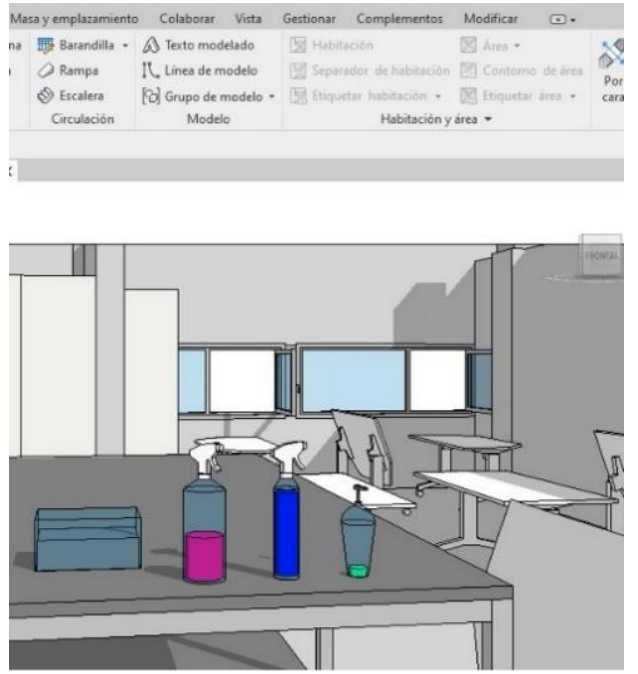

(a)

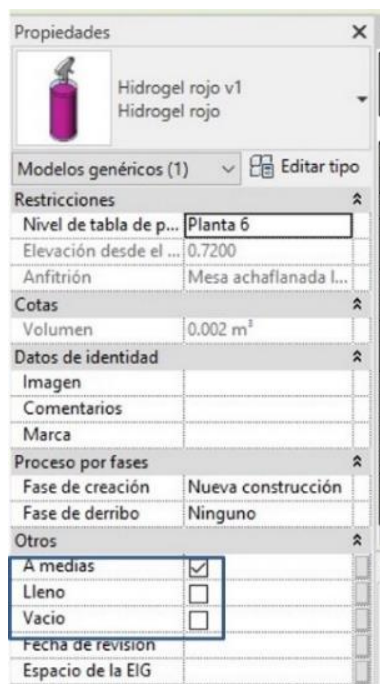

Espacio de la EIC

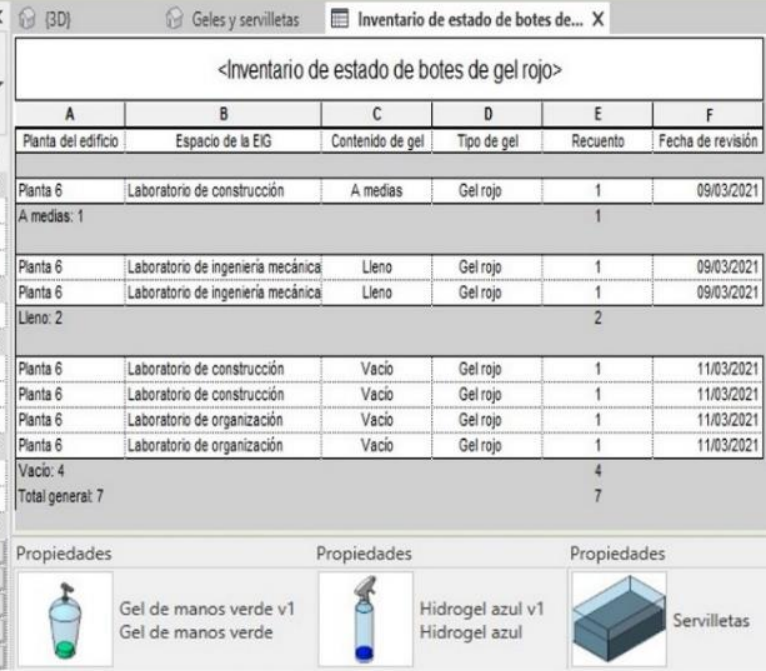

(b)

Figure 13. (a) Digital twin of the cleaning products with the color codes of the physical models (see Figure 6b); (b) Result of the parametric families created for the 4 products, and on the top right, the automatically generated planning tables. The 3 status parameters (full, empty, half-full) are shown in the image.

Preventing the spread of the virus also had an impact on selective waste collection. A new white bin was created for the collection of wipes and products that could have a higher risk of transmitting COVID-19. There are two types of containers inside the classrooms, one for cleaning-related waste (to prevent the transmission of the virus) and another for other types of waste. Outside the classrooms, in the corridors, there are several selective collection points for paper/cardboard, plastic, and organic waste. In addition, in the building foyer, there is a separate collection area for other products such as toners, batteries, pens, and other more specific types of waste.

As with the cleaning products, virtual models of the waste containers were created; in the model these were placed in a geolocated manner that is in the same position as the real containers (Figure 14). 


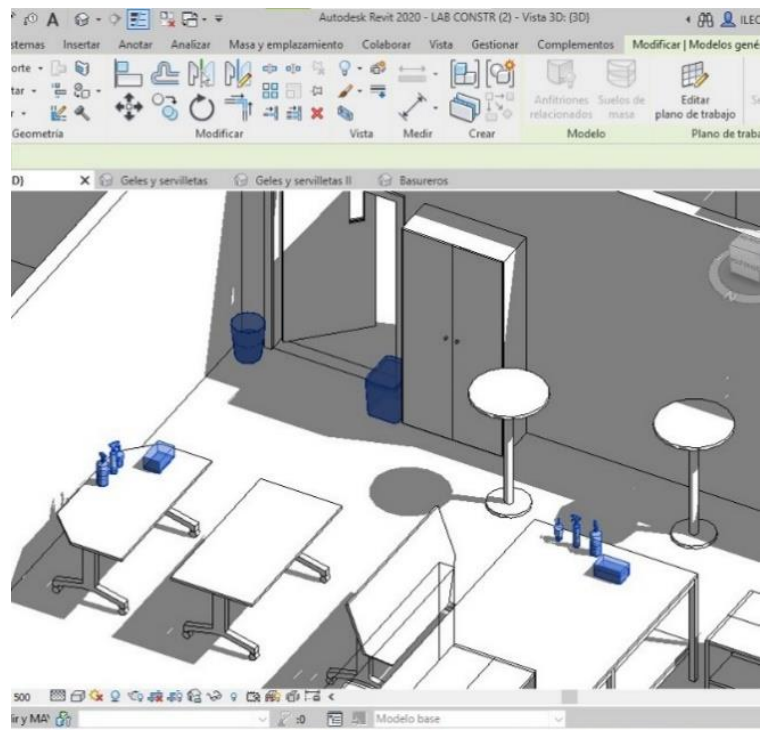

(a)

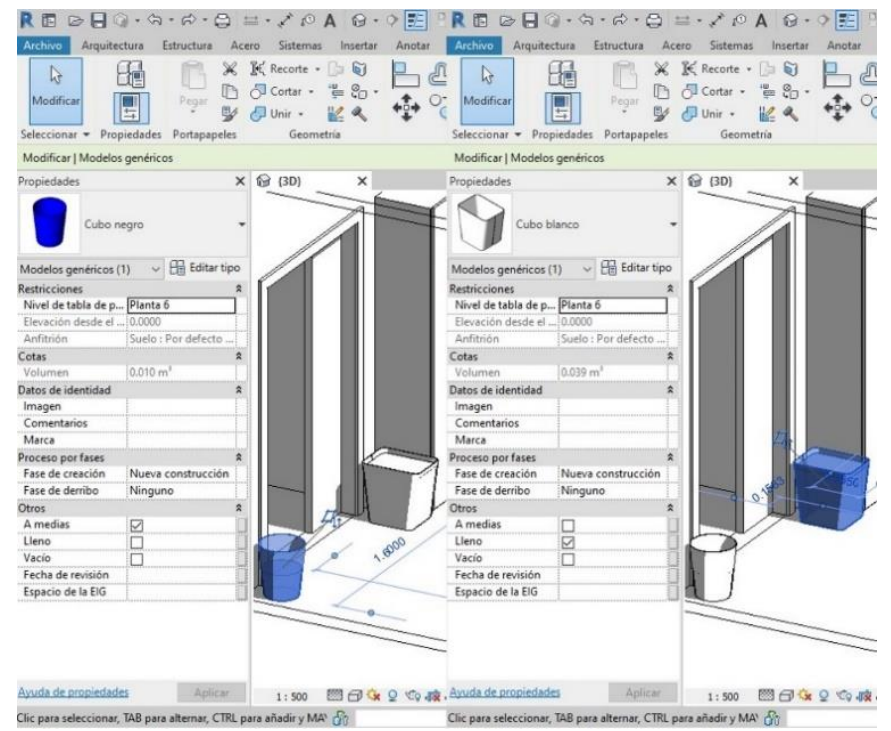

(b)

Figure 14. (a) Location of cleaning products and waste containers in the virtual model; (b) parametric families created specifically in Autodesk Revit, for more sustainable waste control and planning.

The created parametric families work with 3 parameters (i.e., full, empty, half-full), as in the case of cleaning products. This permits keeping track of the volume of waste generated in each space on each floor of the building, or in the building as a whole, and the BIM model can store a permanent record. It also allows for a more efficient management of the collection system by the cleaning service, using planning tables that are automatically generated from the model. In addition, the recording and control of the amount of waste generated permits predicting the actual volume required and the most favorable location for new containers. However, the waste management process has evolved since September 2020 to date. At the beginning, all waste went into the white container, which was the only one left in sight. From January 2021 onwards, separate collection containers for recycling were installed, and in February, new, larger, and more appropriate separate waste collection containers were installed. Stable data on the separate collection of paper/cardboard, plastic, organic, and other waste in the context of COVID-19 are not yet available, but this measurement is in progress, and it will be possible to study these data by June 2021.

\subsubsection{Air Quality Prevention against COVID-19}

Another important issue regarding avoiding contagion in the building focuses on the proper ventilation of the classrooms to avoid the effect of COVID-19 aerosols. As can be read in several publications, there are a few ways to combine appropriate natural ventilation [55]. This issue mainly concerns 3 aspects: opening windows, opening doors, and the increase in heating consumption that occurs. Following the BIM modelling logic of a digital twin of real elements, a parametric family of windows and a parametric family of doors were built virtually (Figure 15). These parametric models enable multiple opening combinations that result in different natural ventilation systems, each having a greater or lesser impact on air renewal. Rapid air renewal is on the side of safety against contagion, but it leads to higher heating consumption, which is contrary to a sustainable management of the school. It is therefore important to test different natural ventilation options that combine and offset the two aspects of safety and responsible consumption of resources. 


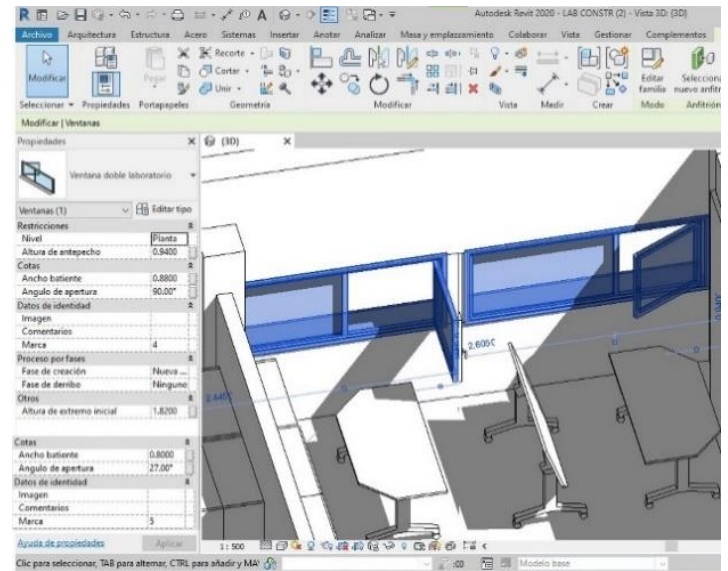

(a)

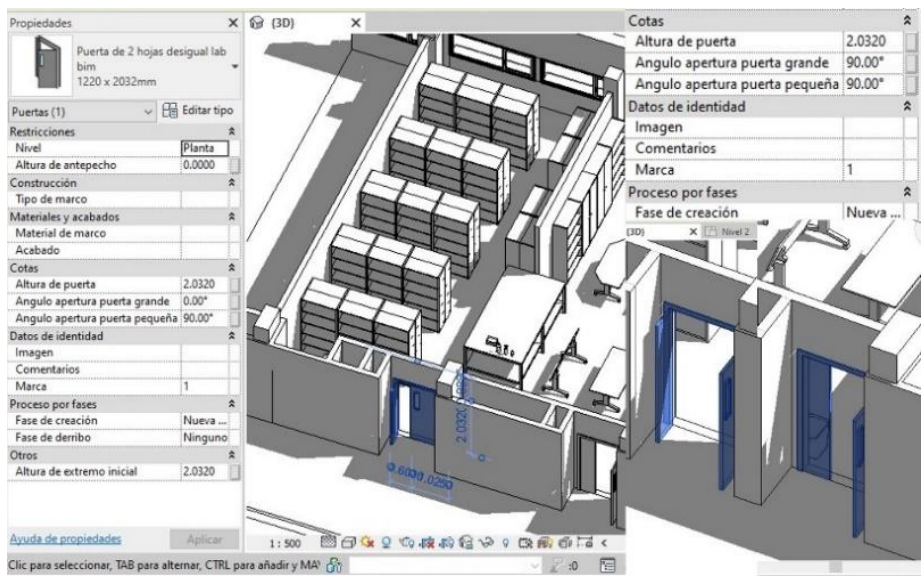

(b)

Figure 15. (a) Parametric family of windows created that permits opening the window at any angle between 0 and $180^{\circ}$; (b) parametric family of doors created that permits opening each sash independently at any angle between 0 and $90^{\circ}$.

The guide for ventilation in classrooms (referred to as Ministerial Guide here), prepared by the Ministry of Science and Innovation, in collaboration with the Institute for Environmental Diagnosis and Water Studies, IDAEA-CSIC Mesura, was taken as a reference. This guide is based on the Harvard University Guide, and on sources and experimental work in ventilation and filtration in Spain [58]. The document mainly presents 4 natural ventilation solutions named R1, R2, R4, and R5. A comparative graph of the 4 types of ventilation is presented, showing the evolution of $\mathrm{CO}_{2}$ in recovery episodes. The graph shows that the 4 systems start with a $\mathrm{CO}_{2}$ concentration of $2000 \mathrm{ppm}$, and over time they all reduce the $\mathrm{CO}_{2}$ concentration at either a slower or faster rate.

By parameterizing the doors and windows in the virtual BIM model, it was possible to test the 4 solutions proposed in the Ministerial Guide for the real physical classroom of the subject (Figure 16). The classroom was equipped with a meter that recorded the $\mathrm{CO}_{2}$ concentration in programmable periods. These conditions can be linked to the BIM model and can be permanently recorded. The model could program maximum $\mathrm{CO}_{2}$ concentration parameters in the classroom; when linked to the real-time measurement, it could alert teachers to switch from one ventilation solution to another and opt for the most sustainable option. In addition, the BIM model could associate heating consumptions in each situation in order to assess the most sustainable option at any given moment while maintaining the necessary safety parameters.

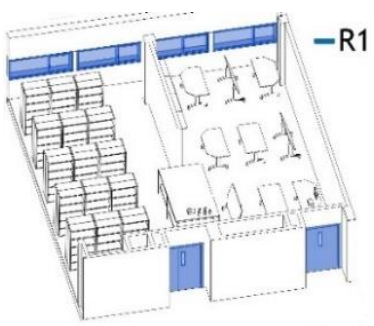

(a)

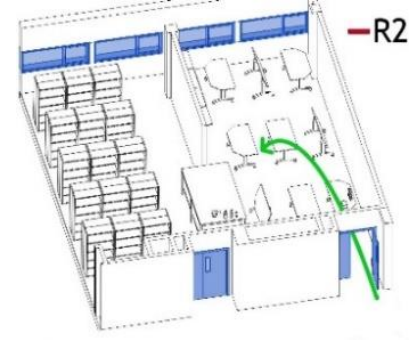

(b)

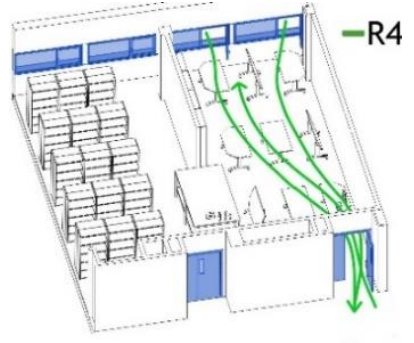

(c)

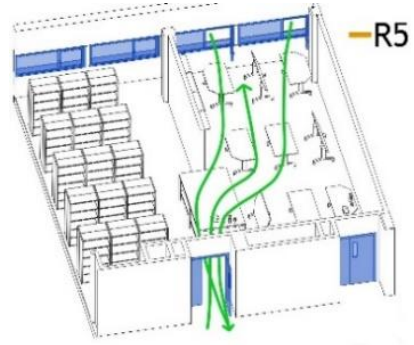

(d)

Figure 16. The 4 natural ventilation options presented in the Ministerial Guide of the Spanish Ministry of Science and Innovation, specifically for the BIM classroom: (a) ventilation solution R1; (b) solution R2; (c) solution R4; (d) solution R5.

The $\mathrm{CO}_{2}$ concentration was measured over several days with two groups of students, with the classroom having two occupancy situations of 10 and 22 people. The initial measurements were programmed every $5 \mathrm{~s}$, but as the data collected showed a constant 
evolution, the measurements continued to be taken every minute. The evolution of the measurements are curves with small occasional variations that can be associated with a line with a constant slope as in the graph of the Ministerial Guide (Figure 17).

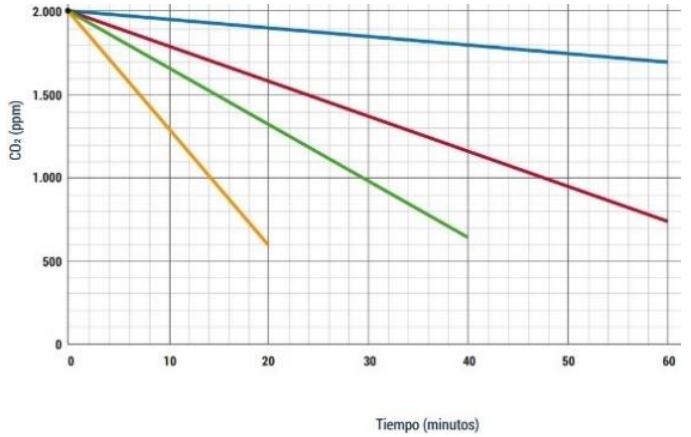

(a)

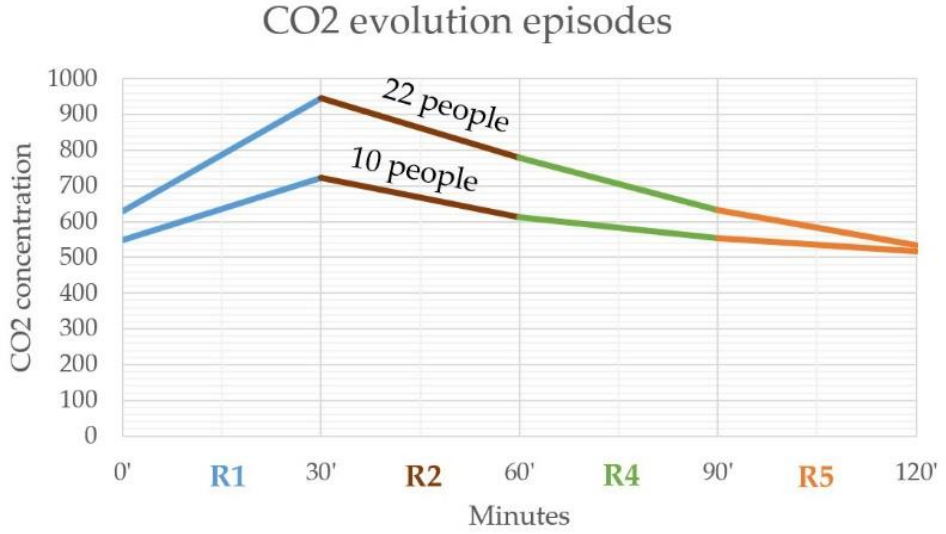

(b)

Figure 17. Graphs of $\mathrm{CO}_{2}$ evolution in natural ventilation recovery periods: (a) graph contained in the IDAEA-CSIC Mesura Ministerial Guide; (b) graphs of the measurements taken with students in the BIM classroom, based on options R1, R2, R4, and R5 proposed in the Ministerial Guide.

Although the results are discussed in general terms in the Discussion section, at this point it is necessary to discuss the difference between the graphs in the Ministerial Guide and the graphs resulting from the measurements taken in real situations with students (Table 3). In the graphs in Figure 17a, the starting point in all cases is 2000 ppm, with a reduction in $\mathrm{CO}_{2}$ concentration occurring over time. This was probably due to the fact that the measurements were taken in the laboratory, starting from an induced $\mathrm{CO}_{2}$ concentration and, as there were no students inside, this concentration decreased over time due to the filtrations that might occur, for example, under the doors.

Table 3. Simplified interpretation of $\mathrm{CO}_{2}$ measurements made in the BIM classroom according to assumptions R1, R2, R4, and $\mathrm{R} 5$ contained in the Ministerial Guide from IDAEA-CSIC Mesura.

\begin{tabular}{|c|c|c|c|c|}
\hline Natural Ventilation Mode & $\begin{array}{l}\text { Classroom with } 10 \text { People } \\
\mathrm{CO}_{2} \text { Concentration (ppm) }{ }^{1}\end{array}$ & $\begin{array}{c}\text { Slope } \\
\text { (ppm/Min) }\end{array}$ & $\begin{array}{c}\text { Classroom with } 22 \text { People } \\
\mathrm{CO}_{2} \text { Concentration (ppm) }{ }^{1}\end{array}$ & Slope \\
\hline R1 & $\begin{array}{l}550 \\
722\end{array}$ & +5.75 & $\begin{array}{l}630 \\
945\end{array}$ & +10.52 \\
\hline $\mathrm{R} 2$ & $\begin{array}{l}722 \\
612\end{array}$ & -3.65 & $\begin{array}{l}945 \\
780\end{array}$ & -5.5 \\
\hline $\mathrm{R} 4$ & $\begin{array}{l}612 \\
553\end{array}$ & -1.96 & $\begin{array}{l}780 \\
632\end{array}$ & -4.94 \\
\hline R5 & $\begin{array}{l}553 \\
517\end{array}$ & -1.2 & $\begin{array}{l}632 \\
535\end{array}$ & -3.23 \\
\hline
\end{tabular}

${ }^{1}$ Taking into account that in their evolution, the $\mathrm{CO}_{2}$ measurements describe a straight line in a simplified manner, the initial and final values were taken to generate the graph, as these values are representative in comparison with those of the Ministerial Guide.

In our case, this also occurs in most situations except in the case of R1. In this situation with closed doors and windows, the $\mathrm{CO}_{2}$ concentration increased, and in periods of more than one hour, it even exceeded twice the initial value, reaching values of $1200 \mathrm{ppm}$ in the classroom with 22 people. This is evident in Table 3, as the angles of the slope of the line in situation $\mathrm{R} 1$ are positive (higher $\mathrm{CO}_{2}$ concentration), while in the rest of the situations the angle is negative $\left(\mathrm{CO}_{2}\right.$ reduction). The greater the negative angle, the greater the $\mathrm{CO}_{2}$ reduction, which is aligned with a lower probability of aerosol concentration. In the case of the graphs in the Ministerial Guide, the slope of the line increases from case R1 to R5, 
because the starting point is always the same, i.e., high and constant. In our real case, as the $\mathrm{CO}_{2}$ concentration decreased from $\mathrm{R} 2$ onwards, the negative slope became less and less steep because it started from an increasingly lower concentration, and it was closer to the concentration with a stable classroom before a lesson. In our graph, case R1 has a positive slope because it is not really a question of ventilation but of higher $\mathrm{CO}_{2}$ concentration, and it is therefore a situation that should be avoided due to the higher risk of COVID-19 aerosol concentration.

\subsection{Quality Education with BIM}

The development of BIM models of education centers-in addition to helping manage the building in general and for the COVID-19 context in particular-brings students closer to the professional world by connecting them with the real problems and challenges that exist in today's society. The development of active methodologies linked to sophisticated ICTs allows students to test the use of the BIM models generated in class and to virtually visualize the results, anticipating the best solutions. As mentioned in Section 2 of the article, the teaching methodology obtained satisfactory results due to having several resources. The results of the production generated, which is linked to the virtual classroom and its assessment system, are presented, and the results of the study of the new resource used in the context of COVID-19 for self-paced learning are visualized by means of videos with different contents. Finally, the results of the BIM models generated in the classroom during this period of time are shown graphically.

\subsubsection{Virtual Classroom for Centralized Work and Evaluation}

The BIM Technology course, based on active methodologies, centralizes all the activity and resources through the virtual classroom in Moodle format, which was customized for the UPV /EHU and is called eGela. The components of the course (i.e., the different theoretical contents programmed, the analysis models, PBL, collaborative activities and/or tasks, server access permits and restrictions, specific assessment rubrics, revitalization of participation and queries, formats and delivery dates, automation of opening deliverables, closures, individual and/or group tutoring, BBC online monitoring classroom, as well as the configuration of the virtual grader of the subject) were planned and programmed before the effective start of the academic year. All activity was automatically evaluated and permanently recorded.

The results of the subject are unbeatable, with a $100 \%$ pass rate among the students taking the subject. This is due, on the one hand, to the interest generated by the development of BIM models closely linked to real professional challenges, and on the other hand, to the rigorous planning of the subject based on active methodologies. The continuous and immediate assessment system is also of paramount importance, taking place in less than $24 \mathrm{~h}$ and based on assessment rubrics with constant feedback. The virtual grader puts students in context at all times and helps them achieve their goals by clearly identifying shortcomings by means of the tactile graphic rubric, where the options for improvement are clearly reflected. Grades are given in boxes that are automatically shaded in green so that students can instantly perceive the summary of the feedback linked to the assessment (Figure 18).

As mentioned in Section 2.1, the 3D BIM models created by the students can be viewed in virtual reality on free platforms such as Sketchfab (https://sketchfab.com accessed on 22 April 2021) or in augmented reality on platforms such as BIMserver.centre (https: / / bimserver.center accessed on 22 April 2021) from the company CYPE Ingenieros. This aspect, in addition to enhancing the students' ability to understand the virtual building, has an additional and very interesting use and is linked to the $100 \%$ virtual teaching stage in the COVID-19 context. The so-called Moodle-eGela "virtual classroom" is not truly a classroom; it is a web platform with different resources, but it is not associated with a three-dimensional virtual reality or environment. These BIM models generated are the perfect virtual scenario to be able to "bring students closer" during the period of distancing 
forced by the obligatory home confinement. This 3D virtual model of the classroom, which simulates the real classroom, has an incredible potential for interpersonal relationships in times of isolation, as students can interact through their avatar, move virtual objects, perform everyday actions that cannot be performed when people are confined (clapping, raising their hands to ask questions, hugging classmates, high-fiving, etc.), all of which can be accompanied by a 3D sound system that allows for conversations with the other avatars who are closer in the virtual model (Figure 19).

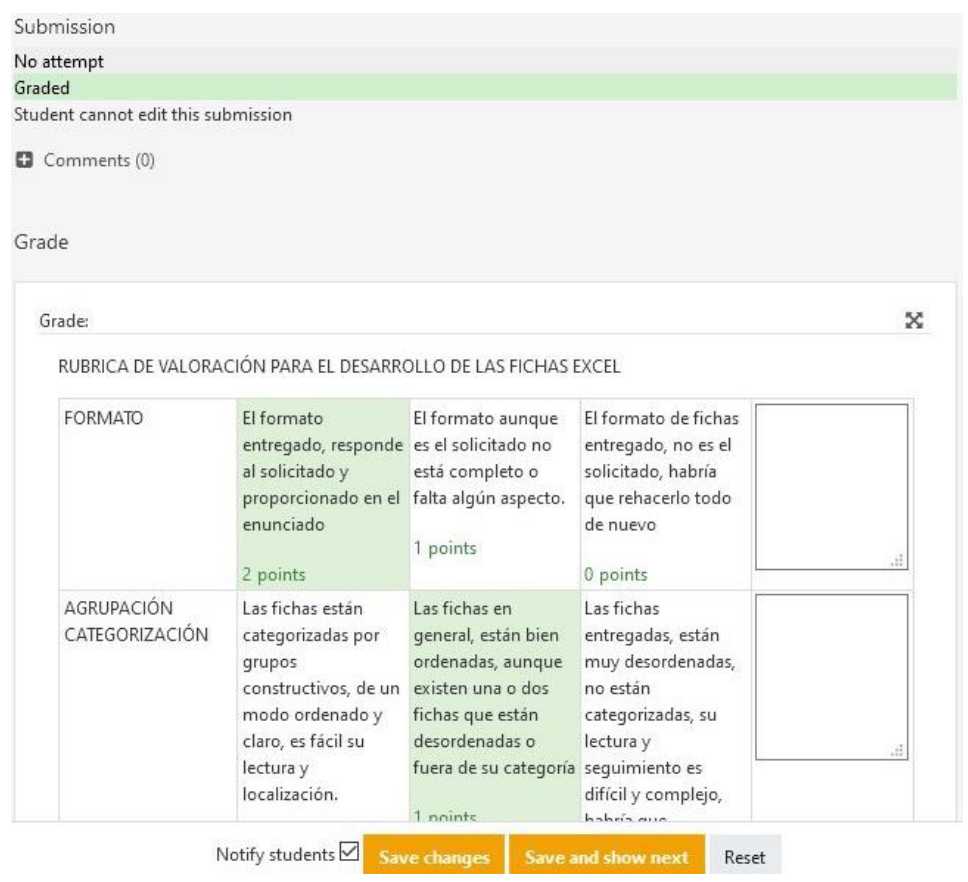

Figure 18. Aspect of the tactile assessment rubric in the virtual classroom.

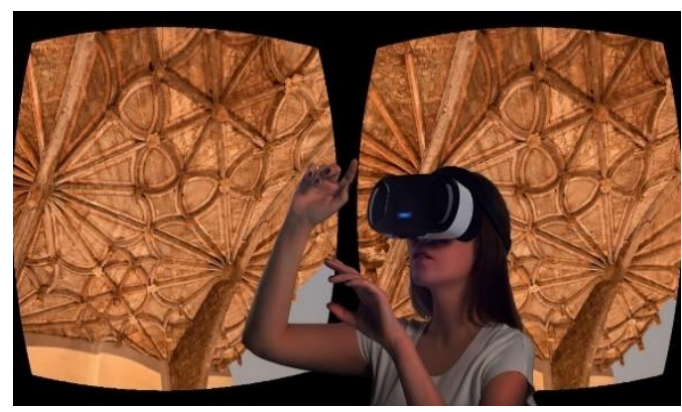

(a)

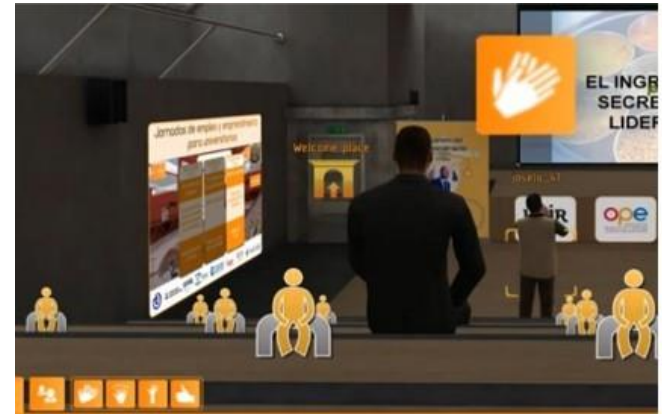

(b)

Figure 19. (a) Virtual model uploaded in Sketchfab for immersion through VR glasses [59]; (b) different actions that can be performed by means of an avatar in a virtual classroom, e.g., clapping, raising a hand to ask a question (Source: VirtwayTech).

\subsubsection{Online Classes with BBC for Learning at One's Own Pace}

In stage 1 of home confinement where classes had to be taught $100 \%$ online, the UPV/EHU made the BBC resource for teaching online classes linked to the eGela virtual classroom, which was available to teachers and students. In addition to being able to activate the resource from the virtual classroom, there is another option to create personalized classrooms through a link. This makes it possible to create classrooms for specific people or particular groups, such as for tutoring final degree or master's degree projects, doctoral theses, etc. In these cases, previously students can upload to the platform the 
documentation they want to be reviewed in .pdf, .jpg or .pptx formats. An extremely interesting functionality is that it permits drawing on shared documents, and so it is a very appropriate resource for correcting the weekly evolution of BIM models (Figure 20a). It also allows a blank whiteboard to be opened for drawing and explanations, permitting the activation of a fixed camera in order to share content and drawings that are developed on the whiteboard. One of the resources that helped to improve teaching is the possibility of easily recording content while the class is being taught. This resource continues to be in use, as it was found to improve teaching and learning through self-paced learning. Self-paced learning means that students can learn through the recorded videos in class in their own time and at their own pace. They can watch as many times as they want; they can stop to practice, rewind, or fast forward at the parts they already understood, which opens up a new field of concept and knowledge retention. Self-paced learning reduces time pressure, eliminates the need for a timetable, reduces distraction, and is suitable for different learning styles [60]. Videos recorded with specific class content are uploaded to YouTube in hidden mode, and it enable students' interest in specific content to be associated with a specific character to be monitored (Figure 20b).

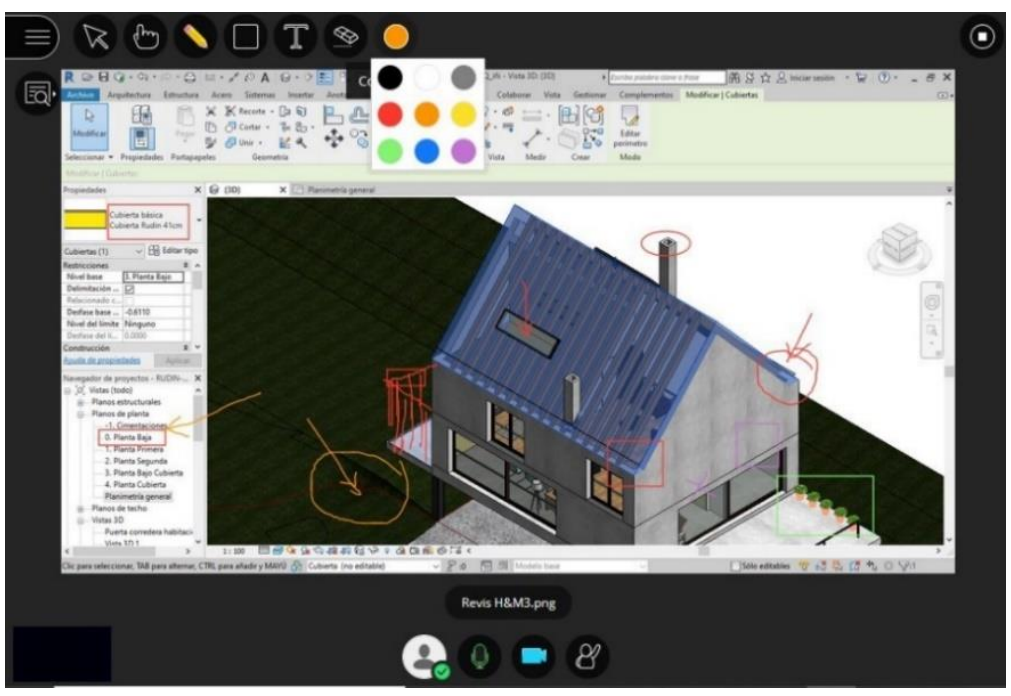

(a)

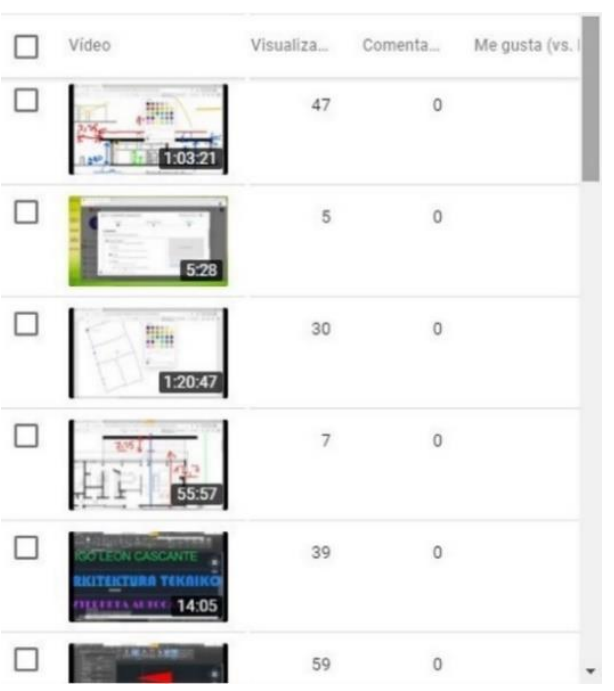

(b)

Figure 20. (a) Correction of BIM models by means of drawing through the BBC platform; (b) list of videos of the class content posted on YouTube, where the interest they create can be monitored.

Recordings made in class are edited and structured into sections. First, there is the theoretical content; second, there is the practical or learning content on how to use specific software; and finally, there is a section for resolving doubts shared by the class, or recommendations to carry out a test. By analyzing the number of video views, it is possible to know which videos are more productive for students, thus aiding teachers in promoting content that is more suited to their needs (Table 4).

Table 4. Analysis of views of class videos posted on YouTube.

\begin{tabular}{cccc}
\hline Type of Video & Number of Views & Number of Videos & Views per Video \\
\hline Theoretical content & 217 & 12 & 18.17 \\
$\begin{array}{c}\text { Practical content } \\
\text { Resolution of } \\
\text { doubts/tests }\end{array}$ & 422 & 18 & 23.44 \\
\hline
\end{tabular}


It can be seen that the most viewed videos are those aimed at resolving specific or generalized student doubts, with an average of 43.11 views per video. However, the videos with theoretical content arouse the least interest, with only 18.17 views per video.

\subsubsection{BIM Models-Central Server-Universal Access}

The course involves research, modelling in Revit, and working with collaborative BIM flows. The challenge posed to students through BIM models reaches Maturity Level 3, i.e., the highest BIM level currently available in the professional market. Real projects are developed with reference buildings in architecture. Once the roles and tasks are assigned to each group, access is restricted to their particular group folder in the virtual space, "Gordetalde", where a member of the group generates the respective central model to be used for each member's 3 different individual local models. Different architecture, structure and MEP models are created, which are linked in a single central model called Master that brings together all the information (Figure 21).

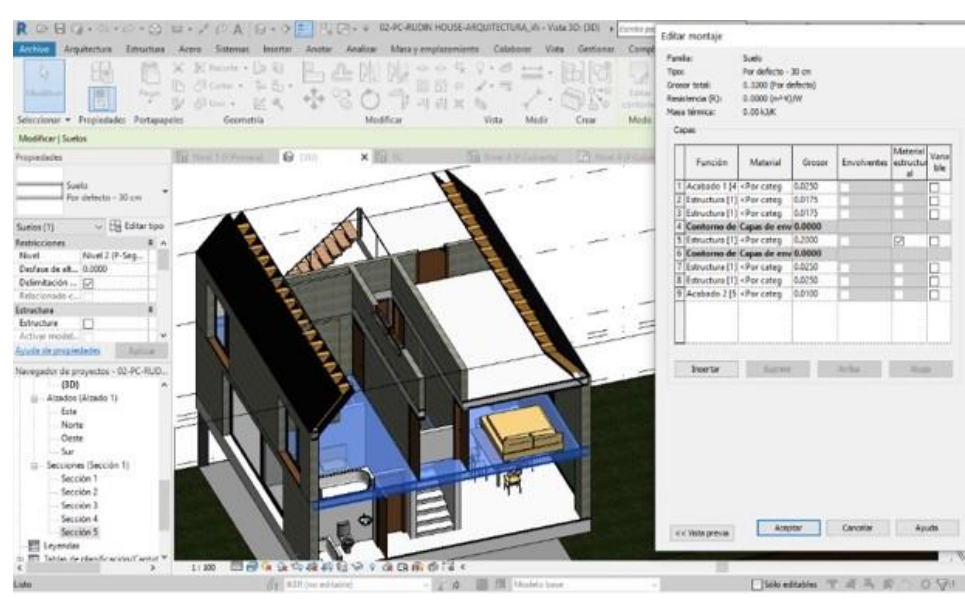

(a)

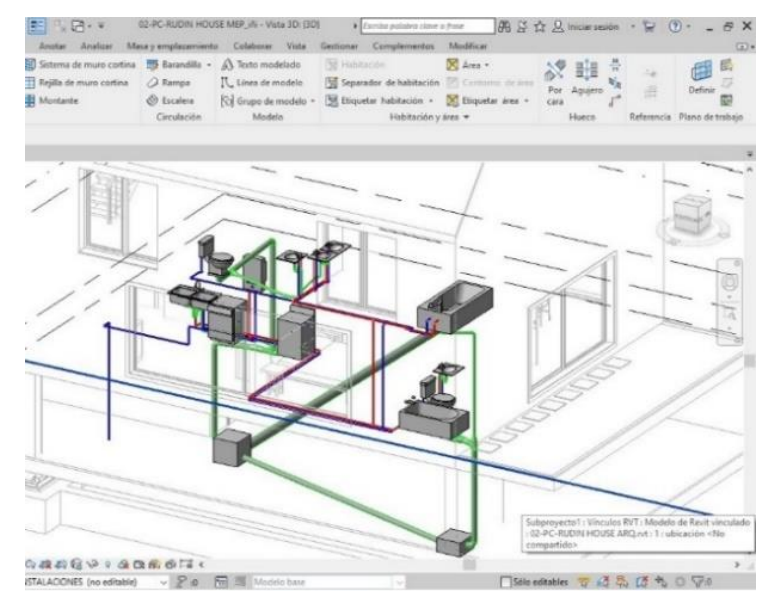

(b)

Figure 21. (a) Central architectural model. Virtual building with the information of all the constructive systems of the real building; (b) MEP model linked to the architectural model, with all the building installations. Cold water, hot domestic water, and sanitation model with all the plumbing appliances.

Students work in different worksets depending on the part of the building they are interested in modelling. These are synchronized in real time and complete the central model that brings together all the information. The work process in the classroom and/or virtual classroom is carried out simultaneously and collaboratively, with the members of each group dedicated to their committed task, and synchronized with the work of their colleagues. Through the UPV/EHU's VPN connection, they can work from private locations, in real time, any day and at any time, without the need for the three members of the group to be present in the physical classroom. After the national confinement decreed on the 14 March 2020, as a result of COVID-19, the students taking our course-that is, students from the Basque Country, from Spain in general, or even international students (Italy, Mexico, France, etc.), who returned to their respective countries-were able to complete the different activities without any problems, with a continuous monitoring of the course. Likewise, the teaching staff, who were also confined, were able to carry out all the monitoring, control, verification, tutoring, and grading activities, thus maintaining the programmed pace.

\section{Discussion}

BIM technology has made it possible to manage the COVID-19 crisis at the university in a more efficient and sustainable way. The use of this learning system was tested, on the one hand, in the management of the education center to solve the new problems associated 
with the safety measures in place to combat the spread of the virus, and on the other hand, by means of BIM virtual models, which made it possible to maintain and even improve the teaching quality.

It is important to highlight the limitations of the research. Regarding the analysis of the teaching system of the BIM course, it must be taken into account that in Spain, a state of emergency was decreed in March 2020 due to COVID-19, and all universities and schools were closed. In less than $48 \mathrm{~h}$, teaching had to be forcibly adapted to a virtual mode, as everyone had to be confined to their homes. This first part of the research was analyzed from the isolation of each home, with no direct contact between the researchers and the students. That is why this first research had a very specific objective, which was to analyze whether the course needed to undergo any modification in its planning and evaluation, with respect to the situation prior to the crisis produced by COVID-19. All the university courses had to adapt their study guides. Indeed, we are not aware of any other experiences where the initial study guide remained intact. In order to understand the importance of the analysis, at the University of the Basque Country alone, there are more than 100 degree programs, in which more than 2400 courses may be taught. If we take into account that in Spain alone there are more than 80 universities, we could be talking about more than 150,000 courses that had to be adapted to the exclusively virtual modality. After the conclusion of the 2020-2021 academic year, we were able to verify that the BIM Technology course, which we taught at the University of the Basque Country, was able to keep the study guide intact before and after confinement. All the tasks were developed, including the group tasks; everything planned was carried out, and the evaluation was conducted following the planning established prior to the confinement. One of the great challenges, and therefore an indisputable limitation, was that the students had to follow the classes from their homes in different countries such as Mexico, France, and Italy, as well as to maintain the group work in real time.

As for the research to adapt the management of the education center to the special circumstances derived from COVID-19, we must highlight the territorial perimeter confinements that we have been suffering. This meant that the research had to be limited to the case study of the faculty where we teach, i.e., the School of Engineering of the University of the Basque Country. In addition to this, the University also follows a strict safety plan against COVID-19 contagion, which limits some ordinary activities, and therefore the collection of monitoring data had to be adapted to these circumstances.

With regard to the management of the education center, three important aspects were evaluated. First, it was possible to study the most sustainable options to meet the requirements of interpersonal distance. It was found that classrooms with fixed desks had to reduce the number of students by almost half. Classrooms with fixed computers, even with nonfixed furniture, also had to reduce their capacity by up to $28 \%$. Only the BIM classrooms with mobile desks and laptops were able to increase their capacity by up to $12 \%$. The BIM model of the building makes it possible to optimize the location of the desks by means of generative design, and this had an impact, for example, on the performance of the lighting systems. Second, the new waste containers and the new specific cleaning points were digitally mirrored in order to prevent the spread of the virus in the classroom. With the BIM model of the different elements, specifically parameterized for this situation, an exhaustive control can be carried out according to the 3 container statuses (i.e., full, half-full, and empty). This made it possible to automatically obtain planning tables that allow for a more efficient management of purchases, product replenishment times, and waste collection. Third, it was possible to analyze different situations to avoid a higher concentration of COVID-19 aerosols by tackling different ventilation options. The parameterization of doors and windows made it possible to analyze the 4 graph options contained in the Spanish Ministerial Guide IDAEA-CSIC Mesura, in the BIM model. By analyzing the $\mathrm{CO}_{2}$ measurements in 2 real situations with 10 and 22 people, it was possible to verify how at least one of the classroom doors must be opened in order to reduce the $\mathrm{CO}_{2}$ concentration. Although the graph in the Ministerial Guide highlights cross ventilation 
between doors and windows as the most effective option, it was found that a combination of options allows the concentration to be progressively reduced, without having to produce a rapid decrease that could lead to higher heating consumption. The still existing restrictions limit the research possibilities at the present time, but in the future, the research can be orientated to analyze other aspects of improvement in the management of the education center using the same BIM model. Among other issues, the possibility of more sustainable management of waste recycling and energy consumption can be analyzed. If the territorial confinement is relaxed, other universities can be visited to contrast different methods used to manage the COVID-19 crisis.

With regard to the management of teaching in this context, the exhaustive planning of a course on a platform that brings together all the information, by means of active methodologies using advanced ICTs, proved that it has overcome the stage of $100 \%$ online teaching with total effectiveness. The use of new resources such as BBC made it easy to record content while the class is being taught, thus fostering the possibility of learning at one's own pace. The videos posted in the virtual classroom allowed the teacher to receive permanent feedback that helps them to redirect the contents to be prepared in order to make the classes more productive. It was found that the videos with practical content, or those that resolve general doubts, were the most viewed, while those with theoretical content were the least viewed. This is why teaching is oriented towards a system of solving challenges through tasks based on real professional practice. In this context, the use of a single BIM model, synchronized in real time from anywhere in the world, helps to avoid the mistakes that occur in a traditional construction workflow. This prepares students from the University to produce a more sustainable construction, which has a positive impact on several SDGs, in addition to Goal 4 linked to quality education.

\section{Conclusions}

The COVID-19 crisis demonstrated the direct relationship between the characteristics of the buildings, where different activities take place, and people's health. The BIM virtual model of a building made it possible to optimize this relationship in order to find the healthiest options by taking into account the most sustainable solutions. With BIM models, it is possible to study, simulate, and monitor more efficient options even in very adverse situations such as in the COVID-19 context. Only in this pandemic context, multiple never before imagined cases that have no simple or obvious solution for the human mind are being managed in an optimal way. In recent months, it was demonstrated that the use of these virtual models still has many unanalyzed uses. The research carried out in this exceptional situation of global pandemic produced by COVID-19 addressed two interrelated areas linked to education.

First, the study focused on analyzing the effectiveness of the teaching provided, based on BIM technology, during the confinement period when both the teaching and evaluations were $100 \%$ virtual. The results of the research show a simple but convincing contribution: the course that was developed with active teaching methodologies through projects, developed with BIM virtual models, supported by different ICTs, and meticulously planned previously in a virtual classroom, was able to develop all the learning competences without suffering any modification, not even in the evaluation system. We know of no other experience at the University of the Basque Country where this occurred; during the confinement, all the subjects had to adapt their study guides to the exclusively virtual modality. Something similar happened with the rest of the universities in Spain, and in the same situation, countries such as France, Italy, etc., continue to suffer the same consequences. At present, a large part of the world is still experiencing a more or less severe confinement, and therefore education continues to be more or less virtual. This allows many other universities to replicate the development of the theoretical knowledge presented in this article.

Second, this work aimed to improve three important aspects within the context of the COVID-19 crisis, linked to the management of the education center by means of BIM 
models. Regarding classroom occupancy and in complying with social distancing, the simulation carried out resulted in a distribution with higher occupancy, which is expected to have an impact on lower lighting consumption. The research carried out made it possible to design and implement the only classroom that managed to increase this figure, resulting in greater sustainability than before the COVID-19 crisis. With regard to disinfection, a model was developed to monitor product consumption. The results show that the consumption of these products can be accurately planned and therefore better adjusted and more sustainable over time. Finally, indoor air quality was monitored according to four assumptions based on previous research of recognized prestige. In agreement with the results, it was possible to rule out one of the solutions to avoid contagion. This monitoring can be included in the BIM model so that the most sustainable natural ventilation solution in real time can be proposed. With these research results, the education center is more sustainable without compromising either safety against contagion or the quality of education. Publishing this research now may allow other universities and education centers around the world to replicate these models and improve in the same field.

Developing teaching based on these BIM models by means of real projects that try to solve social challenges such as the problems linked to COVID-19 allows students to develop a quality education, which is closely linked to the Sustainable Development Goals. This directly affects the preparation of future professionals to resolve imminent setbacks that are expected to affect the planet without neglecting aspects as important as health and sustainability.

Author Contributions: Conceptualization, I.L. and F.M.; methodology, F.M.; software, J.P.O.; validation, I.L., M.S. and F.M.; formal analysis, M.S.; investigation, I.L.; resources, J.P.O.; data curation, M.S.; writing—original draft preparation, I.L.; writing—review and editing, F.M. and J.P.O.; visualization, J.P.O. and M.S.; supervision, I.L. and M.S. All authors have read and agreed to the published version of the manuscript.

Funding: This research received no external funding.

Institutional Review Board Statement: Not Applicable.

Informed Consent Statement: Not Applicable.

Data Availability Statement: The data can be found on the collaboration platform of the University of the Basque Country (https:/ / ehubox.ehu.eus/login?clear=1 accessed on 22 April 2021) and is available for restricted access.

Conflicts of Interest: The authors declare no conflict of interest.

\section{References}

1. United Nations. Transforming Our World: The 2030 Agenda for Sustainable Development. UN General Assembly, 21 October 2015 A/RES/70/1. 2015. Available online: www.refworld.org/docid/57b6e3e44.html (accessed on 29 March 2021).

2. Roberts, L.; Ajai-Ajagbe, P. Higher Education and the Millennium Development Goals: Where Are We Coming From, and Where Are We Going? The Association of Commonwealth Universities, 2013. Available online: http://www.acup.cat/sites/default/ files/beyond-2015-background-report-final_1.pdf (accessed on 29 March 2021).

3. Sustainable Development Solutions Network Australia/Pacific. Getting Started with the SDGs in Universities: A Guide for Universities, Higher Education Institutions, and the Academic Sector. Australia, New Zealand and Pacific Edition. Sustainable Development Solutions Network-Australia/Pacific, Melbourne. 2017. Available online: http://ap-unsdsn.org/wp-content/ uploads/University-SDG-Guide_web.pdf (accessed on 29 March 2021).

4. Leal Filho, W.; Wu, Y.C.J.; Brandli, L.L.; Avila, L.V.; Azeiteiro, U.M.; Caeiro, S.; Madruga, L.R.D.R.G. Identifying and overcoming obstacles to the implementation of sustainable development at universities. J. Integr. Environ. Sci. 2017, 14, 93-108. [CrossRef]

5. Lozano, R.; Ceulemans, K.; Alonso-Almeida, M.; Huisingh, D.; Lozano, F.J.; Waas, T.; Lambrechts, W.; Lukman, R.; Hugé, J. A review of commitment and implementation of sustainable development in higher education: Results from a worldwide survey. J. Clean. Prod. 2015, 108, 1-18. [CrossRef]

6. Leal Filho, W.; Shiel, C.; Paço, A.; Mifsud, M.; Veiga Ávila, L.; Londero Brandli, L.; Molthan-Hill, P.; Pace, P.; Azeiteiro, U.M.; Ruiz Vargas, V.; et al. Sustainable development goals and sustainability teaching at universities: Falling behind or getting ahead of the pack? J. Clean. Prod. 2019, 232, 285-294. [CrossRef] 
7. Sáez de Cámara, E.; Fernández, I.; Castillo-Eguskitza, N. A Holistic Approach to Integrate and Evaluate Sustainable Development in Higher Education. The Case Study of the University of the Basque Country. Sustainability 2021, 13, 392. [CrossRef]

8. University of the Basque Country. Plan Estratégico de la UPV/EHU 2018-2021. 2018. Available online: https: / / www.ehu.eus / es/web/idazkaritza-nagusia/upv-ehuren-plan-estrategikoa-2018-2021 (accessed on 29 March 2021).

9. University of the Basque Country. EHU Agenda for Sustainable Development. 2019. Available online: https://www.ehu.eus / documents/4736101/11938005/EHUAgenda-2030-ENG.pdf/487b2c83-51e1-d0e2-dcd1-af419b2b5c26 (accessed on 29 March 2021).

10. University of the Basque Country. Panel of Indicators for Sustainable Development of the UPV/EHU. 2019. Available online: https:/ / www.ehu.eus/documents/4736101/11938005/EHUagenda2030-Panel-of-indicators.pdf/40e28e80-4e8b-421c-66 e7-6ec589c573d1 (accessed on 29 March 2021).

11. Tilbury, D. Another World Is Desirable: Transforming Higher Education for Sustainability. The Sustainable University: Process and Prospects; Sterling, S., Maxey, L., Luna, H., Eds.; Earthscan/Routledge: London, UK, 2013; ISBN 9780415627740.

12. UNESCO. Education for Sustainable Development Goals: Learning Objectives. 2017. Available online: https:/ / unesdoc.unesco. org/ark:/48223/pf0000247444 (accessed on 29 March 2021).

13. Dhawan, S. Online learning: A panacea in the time of COVID-19 crisis. J. Educ. Tech. Syst. 2020, 49, 5-22. [CrossRef]

14. Luo, H.; Liu, J.; Li, C.; Chen, K.; Zhang, M. Ultra-rapid delivery of specialty field hospitals to combat COVID-19: Lessons learned from the Leishenshan Hospital project in Wuhan. Autom. Constr. 2020, 119, 103345. [CrossRef] [PubMed]

15. Campisi, T.; Acampa, G.; Marino, G.; Tesoriere, G. Cycling Master Plans in Italy: The I-BIM Feasibility Tool for Cost and Safety Assessments. Sustainability 2020, 12, 4723. [CrossRef]

16. Pavon, R.; Alvarez, A.A.; Alberti, M. BIM-Based Educational and Facility Management of Large University Venues. Appl. Sci. 2020, 10, 7976. [CrossRef]

17. Pavon, R.; Alvarez, A.A.; Alberti, M. Possibilities of BIM-FM for the Management of COVID in Public Buildings. Sustainability 2020, 12, 9974. [CrossRef]

18. Li, S.; Xu, Y.; Cai, J.; Hu, D.; He, Q. Integrated environment-occupant-pathogen information modeling to assess and communicate room-level outbreak risks of infectious diseases. Build. Environ. 2021, 187, 107394. [CrossRef]

19. Rice, L. Healthy BIM: The feasibility of integrating architecture health indicators using a building information model (BIM) computer system. Int. J. Arch. Res. 2020, 15, 1-14.

20. Espino-Díaz, L.; Alvarez-Castillo, J.-L.; Gonzalez-Gonzalez, H.; Hernandez-Lloret, C.-M.; Fernandez-Caminero, G. Creating Interactive Learning Environments through the Use of Information and Communication Technologies Applied to Learning of Social Values: An Approach from Neuro-Education. Soc. Sci. 2020, 9, 72. [CrossRef]

21. Espino-Díaz, L.; Fernandez-Caminero, G.; Hernandez-Lloret, C.-M.; Gonzalez-Gonzalez, H.; Alvarez-Castillo, J.-L. Analyzing the Impact of COVID-19 on Education Professionals. Toward a Paradigm Shift: ICT and Neuroeducation as a Binomial of Action. Sustainability 2020, 12, 5646. [CrossRef]

22. Boton, C. Remote Teaching of Building Information Modeling During the COVID-19 Pandemic: A Case Study. Sustainability 2020, 12, 8665. [CrossRef]

23. Agencia Estatal Boletín Oficial del Estado. Available online: https://www.boe.es/buscar/doc.php?id=BOE-A-2020-4609 (accessed on 1 February 2021).

24. Gobierno Vasco, Departamento de Educación, Dirección de Gestión de Personal. Available online: https://www.euskadi. eus/contenidos/informacion/koronavirusa_coronavirus/es_def/adjuntos/medidas_prevencion_202_21_c.pdf (accessed on 1 February 2021).

25. Agencia Estatal Boletín Oficial del Estado. Available online: https://www.boe.es/buscar/doc.php?id=BOE-A-2020-3692 (accessed on 1 February 2021).

26. Universidad del País Vasco-Euskal Herriko Unibertsitatea UPV/EHU-Resolución Rectora-12 Marzo 2020. Available online: https:/ / www.ehu.eus/es/- / errektorea-ebazpenak-koronabirusaren-inguruan (accessed on 1 February 2021).

27. Universidad del País Vasco-Euskal Herriko Unibertsitatea UPV/EHU-Resolución Rectora-14 Marzo 2020. Available online: https: / / www.ehu.eus/es / - resolucion-de-la-rectora-de-14-de-marzo-de-2020-por-la-que-se-suspende-toda-la-actividadpresencial-en-la-upv-ehu-como-consecuencia-del-brote-del-viru (accessed on 1 February 2021).

28. Universidad del País Vasco-Euskal Herriko Unibertsitatea UPV/EHU-Resolución Rectora—8 Abril 2020. Available online: https:/ / www.ehu.eus/es/-/ erabakia-2020ko-apirilaren-8koa-upv-ehuko-errektorearena-upv-ehuren-irakaskuntza-jardueramantentzeko-urruneko-eta-online-modalitateen-bidez-2019-2020 (accessed on 1 February 2021).

29. Universidad del País Vasco-Euskal Herriko Unibertsitatea UPV/EHU-Resolución Rectora-11 Junio 2020. Available online: https://www.ehu.eus/es/- / erabakia-2020ko-ekainaren-11koa-upv-ehuko-errektorearena-aurrez-aurreko-jardueraakademikora-itzultzeari-eta-upv-ehuko-instalazio-eta-ikastegietara-sa (accessed on 1 February 2021).

30. Universidad del País Vasco-Euskal Herriko Unibertsitatea UPV/EHU-Decálogo de Prevención. 2020. Available online: https: / / www.ehu.eus/es/prebentzio-dekalogoa\#Décalogosdeprevenció2 (accessed on 1 February 2021).

31. Universidad del País Vasco-Euskal Herriko Unibertsitatea UPV/EHU-Medidas para el Funcionamiento de los Centros. 2020. Available online: https:/ / www.ehu.eus/es/zentroen-funtzionamendurako-neurriak (accessed on 1 February 2021).

32. Holmström, J.; Ketokivi, M.; Hameri, A.P. Bridging practice and theory: A design science approach. Decis. Sci. 2009, 40, 65-87. [CrossRef] 
33. Simon, H.A. The Sciences of the Artificial; Massachusetts Institute of Technology Press: Cambridge, MA, USA, 1969.

34. Gregor, S.; Hevner, A.R. Positioning and presenting design science research for maximum impact. MIS Q. 2013, 37, $337-355$. [CrossRef]

35. Orro, A.; Novales, M.; Monteagudo, A.; Pérez-López, J.B.; Bugarín, M.R. Impact on City Bus Transit Services of the COVID-19 Lockdown and Return to the New Normal: The Case of A Coruna (Spain). Sustainability 2020, 12, 7206. [CrossRef]

36. Nardell, E.A.; Nathavitharana, R.R. Airborne Spread of SARS-CoV-2 and a Potential Role for Air Disinfection. JAMA. 2020, 324, 141-142. [CrossRef]

37. Monzón-Chavarrías, M.; Guillén-Lambea, S.; García-Pérez, S.; Montealegre-Gracia, A.L.; Sierra-Pérez, J. Heating Energy Consumption and Environmental Implications Due to the Change in Daily Habits in Residential Buildings Derived from COVID-19 Crisis: The Case of Barcelona, Spain. Sustainability 2021, 13, 918. [CrossRef]

38. Marzouk, M.; Azab, S.; Metawie, M. BIM-based approach for optimizing life cycle costs of sustainable buildings. J. Clean. Prod. 2018, 188, 217-226. [CrossRef]

39. Charef, R.; Alaka, H.; Emmitt, S. Beyond the third dimension of BIM: A systematic review of literature and assessment of professional views. J. Build. Eng. 2018, 19, 242-257. [CrossRef]

40. McArthur, J.J. A building information management (BIM) framework and supporting case study for existing building operations, maintenance and sustainability. In Defining the Future of Sustainability and Resilience in Design, Engineering and Construction, Proceedings of the International Conference on Sustainable Design, Engineering and Construction, Chicago, CA, USA, 10-13 May 2015; Chong, W.O., Chang, J., Parrish, K., Berardi, U., Eds.; Elsevier Procedia: Chicago, IL, USA, 2015.

41. Guillen, A.J.; Crespo, A.; Gómez, J.; González Prida, V.; Kobbacy, K.; Shariff, S. Building Information Modeling as Assest Management Tool. IFAC-Papersonline 2016, 49, 191-196. [CrossRef]

42. Official Journal of the European Union, 2014-EUR-Lex. Available online: https:/ / eur-lex.europa.eu/legal-content/ES/TXT/ ?uri=celex\%3A32014L0024 (accessed on 1 February 2021).

43. Agencia Estatal Boletín Oficial del Estado. 2017. Available online: https://www.boe.es/buscar/act.php?id=BOE-A-2017-12902 (accessed on 1 February 2021).

44. IMScadglobal. 2021. Available online: https://www.imscadglobal.com/industries-AEC.php (accessed on 1 February 2021).

45. Azhar, S.; Carlton, W.A.; Olsen, D.; Ahmad, I. Building information modeling for sustainable design and LEED (R) rating analysis. Autom. Constr. 2011, 20, 217-224. [CrossRef]

46. Fernández March, A. Metodologías Activas para la formación de competencias. Educ. Siglo XXI 2006, $24,35-56$.

47. Carrasco, A.; Donoso, J.A.; Duarte, T.; Hernández, J.J.; López, R. Diseño y validación de un cuestionario que mide la percepción de efectividad del uso de metodologías de participación activa (CEMPA). El caso del Aprendizaje Basado en Proyectos (ABPrj) en la docencia de la contabilidad. Innovar 2015, 25, 143-158. [CrossRef]

48. Blumenfeld, P.C.; Soloway, E.; Marx, R.W.; Krajcik, J.S.; Guzdial, M.; Palincsar, A. Motivating Project-Based Learning: Sustaining the Doing, Supporting the Learning. Educ. Psychol. 1991, 26, 369-398.

49. Juárez, M.; Rasskin, I.; Mendo, S. El Aprendizaje Cooperativo, una metodología activa para la educación del siglo XXI: Una revisión bibliográfica. Rev. Pris. Soc. 2019, 26, 200-210.

50. Jiménez, G.; Llitjós, A. El Deducción de calificaciones individuales en actividades cooperativas: Una oportunidad para la coevaluacion y la autoevaluacion en la enseñanza de las ciencias. Rev. Eureka s. Enseñ. y Div. de las Cienc. 2006, 3, $175-187$.

51. Sambell, K.; McDowell, L.; Brown, S. "But is it fair?": An exploratory study of student perceptions of the consequential validity of assessment. Stud. Educ. Eval. 1997, 23, 349-371. [CrossRef]

52. Succar, B. Building information modelling framework: A research and delivery foundation for industry stakeholders. Autom. Constr. 2009, 18, 357-375. [CrossRef]

53. Ham, Y.; Golparvar Fard, M. Mapping actual thermal properties to building elements in gbXML-based BIM for reliable building energy performance modeling. Autom. Constr. 2015, 49, 214-224. [CrossRef]

54. Abualdenien, J.; Borrmann, A. A meta-model approach for formal specification and consistent management of multi-LOD building models. Advan. Eng. Inform. 2019, 40, 135-153. [CrossRef]

55. Tang, P.; Huber, D.; Akinci, B.; Lipman, R.; Lytle, A. Automatic reconstruction of as-built building information models from laser-scanned point clouds: A review of related techniques. Autom. Constr. 2010, 19, 829-843. [CrossRef]

56. Whitehead, H.; Hesselgren, L.; Parrish, J. The Origins of Smartgeometry. In Inside Smartgeometry: Expanding the Architectural Possibilities of Computational Design, AD Smart; Peters, B., Peters, T., Eds.; John Wiley and Sons: Hoboken, NJ, USA, 2013; pp. 20-35.

57. Martin, A.; Hesselgren, L.; Medjdoub, B. PLP Architecture Accessing the Future. In The Changing Shape of Practice: Integrating Research and Design in Architecture; Hensel, M., Nilsson, F., Eds.; Routledge: London, UK, 2016; pp. 61-73.

58. Minguillón, M.C.; Querol, X.; Felisi, J.M.; Garrido, T. Guía para Ventilación en Aulas. Instituto de Diagnóstico Ambiental y Estudios del Agua; CSIC-IDAEA, Ministerio de Ciencia e Innovación y Mesura, 2020. Available online: https: / / www.ciencia.gob. es/stfls/MICINN/Ministerio/FICHEROS/guia_para_ventilacion_en_aulas_csic.pdf (accessed on 29 March 2021).

59. Leon, I.; Pérez, J.J.; Senderos, M. Advanced Techniques for Fast and Accurate Heritage Digitisation in Multiple Case Studies. Sustainability 2020, 12, 6068. [CrossRef]

60. Artino, A. Motivational beliefs and perceptions of instructional quality: Predicting satisfaction with online training. J. Comp. Assist. Learn. 2008, 24, 260-270. [CrossRef] 